medRxiv preprint doi: https://doi.org/10.1101/2021.08.18.21262211; this version posted August 24, 2021. The copyright holder for this preprint (which was not certified by peer review) is the author/funder, who has granted medRxiv a license to display the preprint in perpetuity. It is made available under a CC-BY-NC-ND 4.0 International license.

\title{
Interplay of ADHD polygenic liability with birth-related, somatic and psychosocial factors in ADHD - a nationwide study
}

Isabell Brikell Phd ${ }^{1,2,3}$, Theresa Wimberley Phd ${ }^{1,2,4}$, Clara Albiñana MSc ${ }^{1,2}$, Bjarni Jóhann Vilhjálmsson Phd 1,2,5, Esben Agerbo DrMedSc ${ }^{1,2,4}$, Anders D. Børglum Phd ${ }^{1,6,7}$, Ditte Demontis ${ }^{1,6,7}$, Andrew J. Schork Phd 1,8,9 , Sonja LaBianca Phd ${ }^{1,9}$, Thomas Werge Phd ${ }^{1,9,10,11}$, David M. Hougaard Phd ${ }^{1,12}$, Merete Nordentoft $\mathrm{PhD}^{1,9,13}$, Ole Mors ${ }^{1,14}$, Preben Bo Mortensen Phd ${ }^{1,2,4}$, Liselotte Vogdrup Petersen Phd ${ }^{1,2 *}$, Søren Dalsgaard Phd ${ }^{1,2,4 *}$

1) iPSYCH - The Lundbeck Foundation Initiative for Integrative Psychiatric Research, Copenhagen and Aarhus, Denmark

2) NCRR - National Centre for Register-based Research, Department of Economics and Business Economics, Aarhus University, Aarhus, Denmark

3) Department of Medical Epidemiology and Biostatistics, Karolinska Instituet, Stockholm, Sweden

4) CIRRAU - Centre for Integrated Register-based Research, Aarhus University, Aarhus, Denmark

5) Bioinformatics Research Centre, Aarhus University, Aarhus, Denmark

6) Department of Biomedicine and Centre for Integrative Sequencing, iSEQ, Aarhus University, Aarhus, Denmark

7) Center for Genomics and Personalized Medicine, Central Region Denmark and Aarhus University, Aarhus, Denmark

8) Neurogenomics Division, The Translational Genomics Research Institute (TGEN), Phoenix, AZ, USA

9) Institute of Biological Psychiatry, Mental Health Center Sct. Hans, Mental Health Services Copenhagen, Roskilde, Denmark

10) Department of Clinical Medicine, University of Copenhagen, Copenhagen, Denmark

11) Center for GeoGenetics, GLOBE Institute, University of Copenhagen, Copenhagen, Denmark

12) Department for Congenital Disorders, Statens Serum Institut, Copenhagen, Denmark

13) CORE-Copenhagen Research Centre for Mental Health, Mental Health Services in the Capital Region of Denmark

14) Psychosis Research Unit, Aarhus University Hospital - Psychiatry, Denmark

*These authors contributed equally to the work

Corresponding Author: Dr Isabell Brikell. National Centre for Register-based Research, Department of Economics and Business Economics, Aarhus University, Fuglesangs Allé 26, 8210 Aarhus V, Denmark.

Email: isabell.brikell@ki.se 
medRxiv preprint doi: https://doi.org/10.1101/2021.08.18.21262211; this version posted August 24, 2021. The copyright holder for this preprint (which was not certified by peer review) is the author/funder, who has granted medRxiv a license to display the preprint in perpetuity.

It is made available under a CC-BY-NC-ND 4.0 International license .

\section{Abstract}

Background: ADHD is multifactorial, yet the interplay ADHD polygenic risks scores (ADHD-PRS) and other ADHD associated risk-factors remains relatively unexplored. The aim of this study was to investigate associations, confounding and interactions of ADHD-PRS with birth, somatic and psychosocial risk-factors previously associated with ADHD.

Methods: Participants came from the Danish iPSYCH2012 case-cohort, including a randomly selected general population sample $(N=21,578)$, and all ADHD cases with an ICD-10 diagnosis $F 90.0(N=13,697)$, born in Denmark 1981-2005. We derived ADHD-PRS and identified 25 ADHD risk-factors in Danish national registers. Logistic regression was used to estimate associations of ADHD-PRS with each riskfactors in the general population. Cox models were applied in the full case-cohort to evaluate confounding of risk-factor associations by ADHD-PRS and family psychiatry history, and interactions between ADHD-PRS and each risk-factor.

Results: ADHD-PRS was associated with 14 out of 25 ADHD risk-factors in the general population, e.g., maternal autoimmune disorder, mild traumatic brain injury (TBI), and most psychosocial risk-factors. In the full case-cohort, 21 risk-factors were associated with ADHD diagnosis. Adjusting for ADHD-PRS and parental psychiatric history only led to minor attenuations of these associations. Interactions were observed between ADHD-PRS and sex, maternal autoimmune disease, TBI, paternal employment and age at child-birth.

Conclusion: Higher ADHD-PRS is associated with exposure to certain birth and somatic ADHD risk-factors, and broadly to psychosocial adversity. Evidence of gene-environment interactions were weak and ADHDPRS and/or family psychiatric history have limited confounding effect on ADHD risk-factor associations, suggesting that majority of the investigated risk-factors act largely independently of ADHD-PRS to increase risk of ADHD. 
medRxiv preprint doi: https://doi.org/10.1101/2021.08.18.21262211; this version posted August 24, 2021. The copyright holder for this preprint (which was not certified by peer review) is the author/funder, who has granted medRxiv a license to display the preprint in perpetuity.

It is made available under a CC-BY-NC-ND 4.0 International license .

\section{Introduction}

Attention-deficit/hyperactivity disorder (ADHD) is a prevalent, often persistent neurodevelopmental disorder affecting $5-10 \%$ of children and $2.5-5 \%$ of adults. ${ }^{1,2}$ Family, twin, and genome-wide association studies (GWAS) have demonstrated the importance of genetic factors in ADHD, with heritability estimated at $70-80 \%$ is twins and $22 \%$ from single nucleotide polymorphisms (SNP-based heritability $\left.\left[h^{2}{ }_{S N P}\right]\right) .{ }^{3,4}$ Several birth-related (e.g., low birth), somatic (e.g., infections, seizures), and psychosocial (e.g., low family income, parental psychiatric disorders) factors have also been associated with risk of ADHD..$^{5-8}$ However, the complex interplay between ADHD polygenic liability and such riskfactors (defined here as any attribute, characteristic, or exposure of an individual that increases the likelihood of developing ADHD) is not well understood. ${ }^{6}$ Given that many ADHD risk-factors are themselves heritable, risk-factor associations may in part or fully be mediated by shared genetic effects influencing both the exposure and ADHD. Such effects will be captured by associations between ADHD polygenic liability (both at the family and individual level) and the risk-factor (i.e. geneenvironment correlations), and by attenuated risk-factor outcome associations when accounting for ADHD polygenic liability (i.e. genetic confounding). The impact of a risk-factor may also vary by polygenic liability (i.e., gene-environment interaction). Examining these three types of geneenvironment interplay is important to understand the impact of genes and specific environments on ADHD, and their joint effects, and to identify causal and potentially amenable risk-factors. 9, 10 ADHD is highly polygenic, meaning that hundreds or thousands of common genetic variants, each of small effect size, contribute to its etiology. Thus, polygenic risk scores (PRS), which capture the sum of an individual's risk alleles weighted by their effect size identified through GWAS, is a potentially useful tool for investigating gene-environment interplay. ${ }^{9}$ A recent meta-analysis ${ }^{11}$ found ADHD-PRS to be associated not only with ADHD, but also with measures of lower socioeconomic status. Findings from a population-based cohort of $>7000$ mothers also suggest that ADHD-PRS is associated with certain 
medRxiv preprint doi: https://doi.org/10.1101/2021.08.18.21262211; this version posted August 24, 2021. The copyright holder for this preprint (which was not certified by peer review) is the author/funder, who has granted medRxiv a license to display the preprint in perpetuity.

It is made available under a CC-BY-NC-ND 4.0 International license .

prenatal risk-factors previously associated with neurodevelopment disorders (e.g. infections during pregnancy). ${ }^{12}$ However, research evaluating gene-environment associations is still lacking for many ADHD risk-factors, particularly in the somatic disease domain. ${ }^{11}$

Studies comparing differentially exposed twins and siblings have shown that many risk-factor outcome associations can be largely explained by unmeasured familial genetic and/or environmental confounding. ${ }^{5}$ This suggests that ADHD polygenic liability, measured at the level of the family or the individual, may influence the risk of exposure to certain ADHD risk-factors, even in the absence of an ADHD diagnosis. Parental psychiatric history is often included as a proxy of familial (genetic and/or environmental) confounding in epidemiological studies of ADHD, whereas ADHD-PRS provides a more direct proxy of ADHD polygenic liability captured by current GWAS. However, only a few studies have investigated genetic confounding in ADHD risk-factors associations using both ADHD-PRS and family psychiatric history. ${ }^{13}$ Similarly, there is limited research evaluating gene-environment interactions using ADHD-PRS, with exposures largely limited to socioeconomic indicators and parenting style. ${ }^{11}$ Recent work in the Danish iPSYCH2012 cohort, the world's largest genotyped ADHD sample, found that both ADHD-PRS and several psychosocial risk-factors, including parental psychiatric history, were associated with increased risk of ADHD, yet there was limited evidence of interaction. ${ }^{13}$

In this study, we evaluate gene-environment interplay in the risk of ADHD for 25 birth-related, somatic, and psychosocial factors risk-factors associated with $\mathrm{ADHD}^{5-8}$ and measured in Danish national registers. First, we estimated gene-environment associations between ADHD-PRS and each risk-factors in the general population. Second, we examined the extent to which associations between the risk-factors and ADHD case-control status in iPSYCH2012 are confounded by ADHD-PRS and parental psychiatric history. Finally, we evaluated gene-environment interaction between the risk-factors and ADHD-PRS on ADHD case-control status. 
medRxiv preprint doi: https://doi.org/10.1101/2021.08.18.21262211; this version posted August 24, 2021. The copyright holder for this preprint (which was not certified by peer review) is the author/funder, who has granted medRxiv a license to display the preprint in perpetuity.

It is made available under a CC-BY-NC-ND 4.0 International license .

\section{Methods and Materials}

\section{Sample}

The Integrative Psychiatric Research consortium (iPSYCH) is a case-cohort sample nested within the Danish population born between 1 May 1981 and 31 December $2005 .{ }^{14}$ From this study base, a $2 \%$ ( $N=30000$ ) random population sample (referred to as the subcohort) and all individuals with an ADHD diagnosis F90.0 (coded according to the International Classification of Disease [ICD] $10^{\text {th }}$ edition) were selected. Due to the random selection, 288 individuals with ADHD were selected both as cases and in the subcohort. ADHD diagnoses was obtained from the Danish Psychiatric Central Research Register (DPCRR), which includes psychiatric hospital admissions since 1969 and outpatient admission since $1995 .^{15}$ Genotyping in iPSYCH has been described elsewhere. ${ }^{14}$ For details on imputation, principal components (PC) analysis, and quality control, see Schork et al., (2019). ${ }^{16}$ iPSYCH2012 can be linked to Danish national population registers using the unique personal identification number assigned to everyone registered in Denmark. We restricted our sample to individuals alive and living in Denmark at age five, who were unrelated (no closer than third degree kinship estimated using KING v1.9) and of European ancestry, leaving 13697 ADHD individuals and 21290 non-ADHD individuals in the subcohort. A flowchart describing the study population is presented in Figure S1.

\section{Birth-related, somatic, and psychosocial risk-factors}

To identify birth-related, somatic, and psychosocial risk-factors robustly associated with ADHD in prior literature, we conducted a targeted review of the literature including phenotypic, familial and common genetic variant studies (see Table 1 and supplementary Methods S1). From this review, we selected 25 risk-factor available in Danish national registers. The risk-factors and evidence of association with ADHD are presented in Table 1.

We extracted information on sex, date of birth, migration, death, and parents' personal identification numbers from the Danish Civil Registration System. ${ }^{17}$ We used the Danish Medical Birth Register (DMBR) 
medRxiv preprint doi: https://doi.org/10.1101/2021.08.18.21262211; this version posted August 24, 2021. The copyright holder for this preprint (which was not certified by peer review) is the author/funder, who has granted medRxiv a license to display the preprint in perpetuity.

It is made available under a CC-BY-NC-ND 4.0 International license .

to obtain information on birth weight, gestational age and 5-minute Apgar score. ${ }^{18}$ Somatic diseases in parents (maternal hypertensive disorders and infections during pregnancy, parental autoimmune disorders) and index child (infections, asthma, atopic disease, type 1 diabetes, epilepsy, and traumatic brain injury [TBI]) were identified in The Danish National Patient Register (DNPR), which includes ICDcoded inpatient care since 1977 and outpatient since $1995 .{ }^{19}$ Because asthma and atopic diseases are not routinely treated in specialist care, we also used drug prescriptions from the Danish National Prescription Registry (DPR), which includes information on all prescriptions redeemed at Danish pharmacies since 1995, to identify asthma and atopic disese. ${ }^{20}$ Psychosocial factors (parental income, education, employment status, single parent household, age at delivery) were defined using data from Denmark's socioeconomic registers. ${ }^{21}$ Finally, we parental history for any psychiatric disorder was identified using the DPCRR. Risk-factor definitions are provided in Table S1.

\section{$A D H D$ polygenic risk scores}

We derived ADHD-PRS in iPSYCH201 based on a combination of an externally trained PRS and an internally trained PRS. For details on the method see Albiñana et al (2021)..$^{22}$ Briefly, we used LDPred ${ }^{23}$ the derive an externally trained ADHD-PRS, using SNP weights from the Psychiatric Genomics Consortia cross-disorder ADHD GWAS, not including iPSYCH2012. ${ }^{24}$ We also leveraged having access to individuallevel SNP data on a large number of ADHD individuals by calculating an internally trained ADHD-PRS in an unrelated, European ancestry subset of the iPSYCH2012 sample. SNP weights for the internally trained PRS were obtained from a mixed model prediction implemented in BOLT-LMM. ${ }^{25}$ The final ADHD-PRS was a linear combination of the internally and externally trained ADHD-PRS variables, standardized to the mean and standard deviation in the subcohort.

The iPSYCH2012 study was approved by the Danish Scientific Ethics Committee, the Danish Health Data Authority, the Danish Data Protection Agency, and Danish Newborn Screening Biobank Steering 
medRxiv preprint doi: https://doi.org/10.1101/2021.08.18.21262211; this version posted August 24, 2021. The copyright holder for this preprint (which was not certified by peer review) is the author/funder, who has granted medRxiv a license to display the preprint in perpetuity.

It is made available under a CC-BY-NC-ND 4.0 International license .

Committee. The Danish Scientific Ethics Committee, in accordance with Danish legislation, has, for this study, waived the need for informed consent in biomedical research based on existing biobanks. ${ }^{14,26}$

\section{Statistical analyses}

To obtain population representative estimates of the associations between ADHD-PRS and each ADHD risk-factor, we ran logistic regressions in the $\mathrm{PSYCH} 2012$ subcohort, i.e. a randomly selected general population sample including 288 ADHD individuals. Associations are presented as odds ratios (OR) with 95\% confidence intervals (Cls) per standard deviation (SD) of ADHD-PRS, adjusted for sex, birth-year, and for ancestry using the first four PCs. Exposures that vary over time were defined at the time of ADHDdiagnosis or end of follow-up, whichever came first.

To estimate whether associations between the risk-factors and ADHD may be confounded by ADHD-PRS and parental history of psychiatric disorders, we first confirmed their individual association with ADHD diagnosis. We then used weighted Cox models to estimate the associations of the other 24 risk-factors with ADHD case-control status, adjusted for sex, birth-year and the first four PCs (Model 1). To evaluate confounding by polygenic liability for ADHD, we further adjusted the associations for ADHD-PRS (Model 2), parental psychiatric history (Model 3), and both (Model 4). Analyses were run in the full case-control sample, i.e. all ADHD individuals ( $n=13697$ ) and non-ADHD individuals from the subcohort $(n=21290)$, with age as the underlying time-scale and Kalbfleich and Lawless weights to account for the oversampling of cases. ${ }^{27}$ Individuals were followed from age five until their first ADHD diagnosis, death, emigration, or end of follow-up (i.e. 31 December 2012), whichever came first. Associations are presented as incidence rate ratios (IRRs) with 95\% Cls. In all Cox models, somatic and neurological riskfactors were modelled as time-varying exposures, and remaining risk-factors as time-fixed covariates defined at birth, or prior to the index child's $5^{\text {th }}$ birthday. 
medRxiv preprint doi: https://doi.org/10.1101/2021.08.18.21262211; this version posted August 24, 2021. The copyright holder for this preprint (which was not certified by peer review) is the author/funder, who has granted medRxiv a license to display the preprint in perpetuity. It is made available under a CC-BY-NC-ND 4.0 International license.

Finally, we investigated the potential (multiplicative) interaction between each risk-factor and ADHD-PRS (modelled as a mean centered continuous variable $[$ mean $=0, S D=1]$ ) on the risk of ADHD cases-control status, by modelling a differential linear effect of ADHD-PRS across levels of each risk-factor, using weighted Cox models, adjusted for sex, birth-year, and the first four PCs. 
medRxiv preprint doi: https://doi.org/10.1101/2021.08.18.21262211; this version posted August 24, 2021. The copyright holder for this preprint (which was not certified by peer review) is the author/funder, who has granted medRxiv a license to display the preprint in perpetuity.

It is made available under a CC-BY-NC-ND 4.0 International license .

\section{Results}

The full case-cohort population consisted of 34,987 individuals (14,108 females and 20,879 males), including 13697 diagnosed with ADHD (3606 females and 10,091 males). Mean age at first ADHD diagnosis was 15.6 years in females and males 13.0 years in males.

\section{Gene-environment associations}

In the randomly selected general population sample ( $\mathrm{N}=21,578$, including 288 ADHD individuals), ADHDPRS was significantly associated with 14 out of the 25 ADHD risk-factors (Figure 1 and Table S2). Among birth-related factors, higher ADHD-PRS was associated with being small for gestational age (OR=1.08, 95\% $\mathrm{Cl}=1.03-1.13)$. Among somatic risk-factors, higher ADHD-PRS was associated with maternal autoimmune disorder ( $\mathrm{OR}=1.14,95 \% \mathrm{Cl}=1.05-1.24)$, having had one $(\mathrm{OR}=1.07,95 \% \mathrm{Cl}=1.05-1.10)$ and five or more infections $(\mathrm{OR}=1.14,95 \% \mathrm{Cl}=1.05-1.24$, and mild $\mathrm{TBI}$ (OR=1.11, 95\%Cl=1.05-1.17). Higher ADHDPRS was also associated with majority of the family psychosocial risk-factors, e.g., income in the lowest quintile (maternal $\mathrm{OR}=1.19,95 \% \mathrm{Cl}=1.14-1.24$; paternal $\mathrm{OR}=1.19,95 \% \mathrm{Cl}=1.14-1.24$ ), low education (maternal $\mathrm{OR}=1.16,95 \% \mathrm{Cl}=1.12-1.20$; paternal $\mathrm{OR}=1.17,95 \% \mathrm{Cl}=1.13-1.21$ ), living in single parent household the first five years of life $(\mathrm{OR}=1.26,95 \% \mathrm{Cl}=1.16-1.36)$, age at childbirth $<20$ (maternal $\mathrm{OR}=1.29,95 \% \mathrm{Cl}=1.17-1.42 ;$ paternal $\mathrm{OR}=1.25,95 \% \mathrm{Cl}=1.04-1.50)$, and parental psychiatric history $(1$ parent $\mathrm{OR}=1.13,95 \% \mathrm{Cl}=1.07-1.20 ; 2$ parents $\mathrm{OR}=1.30,95 \% \mathrm{Cl}=1.05-1.61)$.

\section{Genetic confounding}

In the full case-cohort, individuals in the highest ADHD-PRS decile had an increased risk of ADHD, compared to those in the lowest (IRR=4.42,95\%Cl=3.96-4.93), as did individuals with two parents with a history of psychiatric disorders, compared to none (IRR=3.29, 95\% Cl=2.46-4.41) (Figure S2). Twenty-one risk factors were associated with an increased risk of ADHD (Table 2). Within each domain (birthrelated/somatic /psychosocial) the strongest associations were observed for low birthweight $(<2.5 \mathrm{~kg})$ (Model 1 IRR=1.85, 95\%Cl=1.65-2.08), epilepsy (Model 1 IRR=2.38, 95\%Cl=2.06-2.75), and parental at 
medRxiv preprint doi: https://doi.org/10.1101/2021.08.18.21262211; this version posted August 24, 2021. The copyright holder for this preprint (which was not certified by peer review) is the author/funder, who has granted medRxiv a license to display the preprint in perpetuity.

It is made available under a CC-BY-NC-ND 4.0 International license .

elementary school level or less (Model 1 maternal IRR=3.47,95\% $\mathrm{Cl}=3.24-3.72$; paternal IRR=3.68, $95 \% \mathrm{Cl}=3.42-3.96)$. Maternal hypertensive and autoimmune disorders, and atopic disease and type 1 diabetes in the child were not statistically significantly associated with ADHD, with Cls including one. Adjusting the associations for ADHD-PRS (Model 2) or parental psychiatric history (Model 3) alone resulted in very minor changes. Adjusting for both ADHD-PRS and parental psychiatric history (Model 4) lead to attenuation only of the IRR's (i.e., non-overlapping Cl's for minimally adjusted Model 1 and fully adjusted Model 4) for maternal (Model 4 IRR=2.96, 95\%Cl=2.75-3.17) and paternal education at elementary school level or less (Model $4 \mathrm{IRR}=3.15,95 \% \mathrm{Cl}=2.92-3.40$ ), compared to an academic degree.

\section{Gene-environment interaction}

Results from the Cox models including interaction terms between the continuous ADHD-PRS and each risk-factor on the risk of ADHD are presented in Table S3. Evidence of interaction ( $p$-value $<0.05)$ was observed between ADHD-PRS and sex, maternal autoimmune disease, TBI, paternal unemployment and paternal age at birth of index child (Figure 2). For example, higher ADHD-PRS had a somewhat larger effect on risk of ADHD in females (Females IRR=1.60, 95\%Cl=1.54-1.67; Males IRR=1.51, 95\%Cl=1.471.56), in individuals with no TBI (IRR=1.54, 95\%Cl=1.50-1.59) or severe TBI (IRR=1.64, 95\%Cl=1.35-1.99), compared to mild TBI (IRR=1.36, 95\%Cl=1.26-1.48), and in children of fathers outside the workforce (IRR $=2.44,95 \% \mathrm{Cl}=1.75-3.39]$; employed $\mathrm{IRR}=1.53,95 \% \mathrm{Cl}=1.50-1.57)$. Further, the effect of ADHD-PRS on ADHD diagnosis was lower in children of mothers with an autoimmune disorder (IRR=1.19, 95\%Cl=1.051.35) than in mothers without an autoimmune disorder ( $\mathrm{RR}=1.53,95 \% \mathrm{Cl}=1.49-1.57)$. This was also the only the interaction to survive false discovery rate (FDR) correction $(p<0.009)$ for multiple testing (Table S3). 
medRxiv preprint doi: https://doi.org/10.1101/2021.08.18.21262211; this version posted August 24, 2021. The copyright holder for this preprint (which was not certified by peer review) is the author/funder, who has granted medRxiv a license to display the preprint in perpetuity.

It is made available under a CC-BY-NC-ND 4.0 International license .

\section{Discussion}

We investigated three types of gene-environment interplay (association, confounding and interaction) in ADHD, using ADHD-PRS and a broad range of risk-factors. ADHD-PRS was associated with 14 out of 25 evaluated risk-factors, including certain birth-related and somatic risk-factors, and psychosocial riskfactors expect paternal employment in the general population. Nevertheless, ADHD-PRS and/or parental psychiatric history had minimal confounding effect on the phenotypic association of these risk-factors and ADHD diagnosis. Finally, we observed tentative support for gene-environment interactions for six risk-factors, including TBI, paternal employment and age at birth of index child.

We present a targeted review of prior literature linking ADHD to the risk-factors included in this study at the phenotypic, familial and common genetic variant level. We replicate majority of these associations in a population-based sample including 13,697 ADHD individuals. Moreover, we show that in the general population, higher ADHD-PRS is associated with exposure to several ADHD risk-factors, albeit with small effect sizes. Together with prior reserach, ${ }^{11,13}$ this highlights that gene-environment associations appear to be pervasive in ADHD, particularly for psychosocial adversity. We replicate previous findings in iPSYCH $2012^{13}$ of ADHD-PRS being associated with parental unemployment, lower education, income, and psychiatric disorders. We add to this by showing that higher ADHD-PRS is also associated with growing up in a single parent household and being born to young parents. Similar ADHD genetic correlations with lower educational attainment and younger age at child-birth have previously been reported in the UK Biobank (Table 1). Further, ADHD-PRS was associated with being small for gestational age, $\mathrm{TBI}$, and infections in childhood, suggesting that these ADHD risk-factor association arise in part through shared genetic mechanisms.

Despite evidence for gene-environment associations, ADHD-PRS and parental history of psychiatric disorders had only minimal confounding effects on these associations between risk-factors and ADHD case-control status. However, we cannot rule out substantial residual genetic confounding as current 
medRxiv preprint doi: https://doi.org/10.1101/2021.08.18.21262211; this version posted August 24, 2021. The copyright holder for this preprint (which was not certified by peer review) is the author/funder, who has granted medRxiv a license to display the preprint in perpetuity.

It is made available under a CC-BY-NC-ND 4.0 International license .

ADHD-PRS only explains $\sim 5 \%$ of variance in $\mathrm{ADHD}^{3}$ and register coverage of parental ADHD diagnoses is limited as ADHD only recently stared being diagnosed in adults. ${ }^{2,4}$ Our results highlight that adjusting for ADHD-PRS and parental psychiatric history is unlikely to fully capture familial/genetic confounding, suggesting that researchers aiming to identify causal risk-factors for ADHD should consider other genomic and/or family-based methods to address genetic confounding. ${ }^{5,28}$ Further, our finding indicate that ADHD-PRS and parental psychiatric history act largely independently of the other investigated risk-factors in the development of ADHD.

We observed interactions between ADHD-PRS and sex, maternal autoimmune disease, TBI, and parental employment and age at child-birth. For instance, children with higher ADHD-PRS whose fathers were outside the workforce or young ( $<20$ years) at child-birth had more elevated risk of ADHD, compared to those with none or only one of these risk-factors. These findings may in part be explained by undiagnosed ADHD in fathers, as younger parenthood and unemployment is linked to ADHD (Table 1). Unlike prior work in iPSYCH, ${ }^{29}$ we observed an interaction of ADHD-PRS with sex. However, the effect was small and should be interpreted with be given the large prevalence difference of ADHD in boys and girls. ${ }^{2}$ Overall, there was limited evidence of gene-environment interactions, in line with the few ADHD-PRS interaction studies conducted so far. ${ }^{11}$ It should also be noted that only the interaction of ADHD-PRS with maternal autoimmune disorder survived multiple-testing correction, and given that maternal autoimmune disorder did not have a main effect on ADHD, the results are difficult to interpret. Utilizing PRS to detect gene-environment interaction is challenging, both due to low power and because disorder predictive PRSs do not necessarily capture genetic variants linked to a differential susceptibility to risk exposure. ${ }^{9}$ Nevertheless, investigating gene-environment interplay may elucidate heterogeneous pathways to ADHD; we highlight three examples here. First, epilepsy was associated with a 2.3-fold increased risk of ADHD, but with no evidence for associations or interactions between epilepsy and ADHD-PRS. Prior studies also do not support a strong common genetic overlap between epilepsy and 
medRxiv preprint doi: https://doi.org/10.1101/2021.08.18.21262211; this version posted August 24, 2021. The copyright holder for this preprint (which was not certified by peer review) is the author/funder, who has granted medRxiv a license to display the preprint in perpetuity.

It is made available under a CC-BY-NC-ND 4.0 International license .

ADHD (Table 1), suggesting that epilepsy may act as an independent pathway to ADHD (e.g., through neuronal insults), or that the disorders associate due to common environmental and/or rare genetic riskfactors. Second, mild TBI has been linked to ADHD, yet it remains unclear whether the association is causal, as untreated ADHD is itself a risk for accidents and injuries. ${ }^{30}$ In support of this, we found higher ADHD-PRS to be associated with higher risk of TBI. We also observed that the effect of ADHD-PRS on ADHD risk was stronger in those with no or severe TBI. Similarly, one prior study found ADHD-PRS to be associated with higher ADHD traits in youth without TBI, but not in those with mild TBI. ${ }^{31}$ Together, this suggests that individuals with a mild TBI may require a lower genetic burden to be diagnosed with ADHD. Finally, our results add to a growing body of evidence linking ADHD to immune-related diseases (Table 1). ADHD-PRS was associated with maternal autoimmune disease and early life infections. Moreover, maternal autoimmune disease showed evidence of interaction with ADHD-PRS, potentially suggesting that autoimmune/inflammatory diseases impact on ADHD risk both through a shared genetic vulnerability and through neuro-inflammatory pathways. ${ }^{32}$

\section{Limitations}

Our findings must be interpreted in light of several limitations. First, although this study represent the largest and most comprehensive investigation of gene-environment interplay using ADHD-PRS to date, we may still have been underpowered to detect interactions of modest effect sizes, and we were limited to studying risk factor recorded with sufficient coverage in the Danish national registers. Second, our sample included clinically treated ADHD individuals with an ICD-10 diagnosis F90.0, meaning our findings may not extend to the broader ADHD population. Third, our analyses were restricted to individuals of European ancestry, which may limit generalizability to populations of other ancestry. Third, studying interactions with PRS is challenging; if included SNPS do not interact with the exposures in a similar way, interactions may be diluted, and SNPs associated with ADHD case-control status are not necessarily the genetic variants most strongly linked to a potential differential susceptibility to risk-factor exposure., ${ }^{9,33}$ 
medRxiv preprint doi: https://doi.org/10.1101/2021.08.18.21262211; this version posted August 24, 2021. The copyright holder for this preprint (which was not certified by peer review) is the author/funder, who has granted medRxiv a license to display the preprint in perpetuity.

It is made available under a CC-BY-NC-ND 4.0 International license.

Conclusion

ADHD polygenic liability increases the risk of both ADHD diagnosis and exposure to risk-factors associated with ADHD. Our findings underscore the importance of accounting for genetic confounding in order to identify causal risk-factors, and highlight that ADHD-PRS and family psychiatric history are unlikely to fully capture such confounding. We present suggestive evidence for gene-environment interactions between ADHD-PRS and certain risk-factors, illustrating potential different pathways to ADHD. As genotyped samples with information on both ADHD and associated risk-factors increase, future research should explore the mechanism underlying observed gene-environment associations and interactions in ADHD using complimentary methods such as genome-wide by environment interaction studies or plasticity PRS. ${ }^{9}$ 
medRxiv preprint doi: https://doi.org/10.1101/2021.08.18.21262211; this version posted August 24, 2021. The copyright holder for this preprint (which was not certified by peer review) is the author/funder, who has granted medRxiv a license to display the preprint in perpetuity.

It is made available under a CC-BY-NC-ND 4.0 International license.

\section{Acknowledgments}

The iPSYCH team was supported by grants from the Lundbeck Foundation (R102-A9118, R155-2014-1724 and R248-2017-2003), the European Union's FP7 Program (Grant No. 602805, “Aggressotype”), the European Union's Horizon 2020 Program (Grant No. 667302, “CoCA”), NIMH (1U01MH109514-01 to Dr. Borglum), and the universities and university hospitals of Aarhus and Copenhagen. The Danish National Biobank resource was supported by the Novo Nordisk Foundation. High-performance computer capacity for handling and statistical analysis of IPSYCH data on the GenomeDK HPC facility was provided by the Center for Genomics and Personalized Medicine and the Centre for Integrative Sequencing, iSEQ, Aarhus University, Denmark (grant to ADB). Dr. Dalsgaard's research is further supported by Helsefonden (grant no 19-8-0260) and the European Union's Horizon 2020 Program (Grant No 847879). Dr. LaBianca acknowledges support from the Research Fund of the Mental Health Services - Capital Region of Denmark R4A92.

\section{Disclosures}

Dr Ditte Demontis has received speaking fee from Takeda, outside the submitted work. Remaining authors reports no financial relationships with commercial interests. 
medRxiv preprint doi: https://doi.org/10.1101/2021.08.18.21262211; this version posted August 24, 2021. The copyright holder for this preprint (which was not certified by peer review) is the author/funder, who has granted medRxiv a license to display the preprint in perpetuity. It is made available under a CC-BY-NC-ND 4.0 International license .

\section{References}

1. Simon V, Czobor P, Balint S, Meszaros A, Bitter I. Prevalence and correlates of adult attentiondeficit hyperactivity disorder: meta-analysis. Br J Psychiatry 2009; 194(3): 204-211.

2. Polanczyk G, de Lima MS, Horta BL, Biederman J, Rohde LA. The worldwide prevalence of ADHD: a systematic review and metaregression analysis. The American journal of psychiatry 2007; 164.

3. Demontis D, Walters RK, Martin J, Mattheisen M, Als TD, Agerbo E et al. Discovery of the first genome-wide significant risk loci for attention deficit/hyperactivity disorder. Nature Genetics 2019; 51: 63-75.

4. Brikell I, Burton C, Mota NR, Martin J. Insights into attention-deficit/hyperactivity disorder from recent genetic studies. Psychological Medicine 2021: 1-13.

5. Carlsson T, Molander F, Taylor MJ, Jonsson U, Bölte S. Early environmental risk factors for neurodevelopmental disorders - a systematic review of twin and sibling studies. Development and Psychopathology 2020: 1-48.

6. Kim JH, Kim JY, Lee J, Jeong GH, Lee E, Lee S et al. Environmental risk factors, protective factors, and peripheral biomarkers for ADHD: an umbrella review. The Lancet Psychiatry 2020; 7(11): 955-970.

7. Faraone SV, Banaschewski T, Coghill D, Zheng Y, Biederman J, Bellgrove MA et al. The World Federation of ADHD International Consensus Statement: 208 Evidence-based Conclusions about the Disorder. Neurosci Biobehav Rev 2021.

8. Russell AE, Ford T, Williams R, Russell G. The Association Between Socioeconomic Disadvantage and Attention Deficit/Hyperactivity Disorder (ADHD): A Systematic Review. Child psychiatry and human development 2016; 47(3): 440-458.

9. Zhang X, Belsky J. Three phases of Gene $\times$ Environment interaction research: Theoretical assumptions underlying gene selection. Dev Psychopathol 2020: 1-12.

10. van der Mei IAF, Otahal P, Simpson S, Taylor B, Winzenberg T. Meta-Analyses to Investigate Gene-Environment Interactions in Neuroepidemiology. Neuroepidemiology 2014; 42: 39-49.

11. Ronald A, de Bode N, Polderman TJC. Systematic Review: How the AttentionDeficit/Hyperactivity Disorder Polygenic Risk Score Adds to Our Understanding of ADHD and Associated Traits. Journal of the American Academy of Child \& Adolescent Psychiatry 2021.

12. Leppert B, Havdahl A, Riglin L, Jones HJ, Zheng J, Davey Smith G et al. Association of Maternal Neurodevelopmental Risk Alleles With Early-Life Exposures. JAMA Psychiatry 2019.

13. Østergaard SD, Trabjerg BB, Als TD, Climent CA, Privé F, Vilhjálmsson BJ et al. Polygenic risk score, psychosocial environment and the risk of attention-deficit/hyperactivity disorder. Translational Psychiatry 2020; 10(1): 335. 
medRxiv preprint doi: https://doi.org/10.1101/2021.08.18.21262211; this version posted August 24, 2021. The copyright holder for this preprint (which was not certified by peer review) is the author/funder, who has granted medRxiv a license to display the preprint in perpetuity. It is made available under a CC-BY-NC-ND 4.0 International license .

14. Pedersen CB, Bybjerg-Grauholm J, Pedersen MG, Grove J, Agerbo E, Baekvad-Hansen M et al. The iPSYCH2012 case-cohort sample: new directions for unravelling genetic and environmental architectures of severe mental disorders. Mol Psychiatry 2017.

15. Mors O, Perto GP, Mortensen PB. The Danish Psychiatric Central Research Register. Scandinavian journal of public health 2011; 39: 54-57.

16. Schork AJ, Won H, Appadurai V, Nudel R, Gandal M, Delaneau O et al. A genome-wide association study of shared risk across psychiatric disorders implicates gene regulation during fetal neurodevelopment. Nature Neuroscience 2019; 22: 353-361.

17. Pedersen CB, Gøtzsche H, Møller $\emptyset \emptyset$, Mortensen PB. The Danish Civil Registration System. A cohort of eight million persons. Danish medical bulletin 2006; 53: 441-449.

18. Bliddal M, Broe A, Pottegård A, Olsen J, Langhoff-Roos J. The Danish Medical Birth Register. Eur J Epidemiol 2018; 33(1): 27-36.

19. Lynge E, Sandegaard JL, Rebolj M. The Danish National Patient Register. Scandinavian journal of public health 2011; 39: 30-33.

20. Pottegård A, Schmidt SAJ, Wallach-Kildemoes H, Sørensen HT, Hallas J, Schmidt M. Data Resource Profile: The Danish National Prescription Registry. International Journal of Epidemiology 2017; 46: 798-798f.

21. Petersson $F$, Baadsgaard $M$, Thygesen LC. Danish registers on personal labour market affiliation. Scandinavian journal of public health 2011; 39: 95-98.

22. Albiñana C, Grove J, McGrath JJ, Agerbo E, Wray NR, Bulik CM et al. Leveraging both individuallevel genetic data and GWAS summary statistics increases polygenic prediction. American journal of human genetics 2021; 108(6): 1001-1011.

23. Vilhjálmsson BJ, Yang J, Finucane HK, Gusev A, Lindström S, Ripke S et al. Modeling Linkage Disequilibrium Increases Accuracy of Polygenic Risk Scores. American journal of human genetics 2015; 97: 576-592.

24. Cross-Disorder Group of the Psychiatric Genomics C. Identification of risk loci with shared effects on five major psychiatric disorders: a genome-wide analysis. The Lancet 2013; 381(9875): 13711379.

25. Loh P-R, Tucker G, Bulik-Sullivan BK, Vilhjálmsson BJ, Finucane HK, Salem RM et al. Efficient Bayesian mixed-model analysis increases association power in large cohorts. Nature Genetics 2015; 47: 284-290.

26. Mortensen PB. Response to "Ethical concerns regarding Danish genetic research". Molecular Psychiatry, vol. 24. Nature Publishing Group2019, pp 1574-1575.

27. Petersen L, Sørensen TIA, Andersen PK. Comparison of case-cohort estimators based on data on premature death of adult adoptees. Statistics in Medicine 2003; 22: 3795-3803. 
medRxiv preprint doi: https://doi.org/10.1101/2021.08.18.21262211; this version posted August 24, 2021. The copyright holder for this preprint (which was not certified by peer review) is the author/funder, who has granted medRxiv a license to display the preprint in perpetuity. It is made available under a CC-BY-NC-ND 4.0 International license .

28. Pingault J-B, O'Reilly PF, Schoeler T, Ploubidis GB, Rijsdijk F, Dudbridge F. Using genetic data to strengthen causal inference in observational research. Nature Reviews Genetics 2018.

29. Martin J, Walters RK, Demontis D, Mattheisen M, Lee SH, Robinson E et al. A Genetic Investigation of Sex Bias in the Prevalence of Attention-Deficit/Hyperactivity Disorder. Biological Psychiatry 2018; 83(12): 1044-1053.

30. Dalsgaard S, Leckman JF, Mortensen PB, Nielsen HS, Simonsen M. Effect of drugs on the risk of injuries in children with attention deficit hyperactivity disorder: a prospective cohort study. The Lancet Psychiatry 2015; 2(8): 702-709.

31. Stojanovski S, Felsky D, Viviano JD, Shahab S, Bangali R, Burton CL et al. Polygenic Risk and Neural Substrates of Attention-Deficit/Hyperactivity Disorder Symptoms in Youths With a History of Mild Traumatic Brain Injury. Biological Psychiatry 2019; 85(5): 408-416.

32. Dunn GA, Nigg JT, Sullivan EL. Neuroinflammation as a risk factor for attention deficit hyperactivity disorder. Pharmacology, biochemistry, and behavior 2019; 182: 22-34.

33. Aschard H. A perspective on interaction effects in genetic association studies. Genetic Epidemiology 2016; 40(8): 678-688.

34. Franz AP, Bolat GU, Bolat H, Matijasevich A, Santos IS, Silveira RC et al. Attentiondeficit/hyperactivity disorder and very preterm/very low birth weight: A meta-analysis. Pediatrics, vol. 141. American Academy of Pediatrics2018.

35. Sciberras E, Mulraney M, Silva D, Coghill D. Prenatal Risk Factors and the Etiology of ADHDReview of Existing Evidence. Current psychiatry reports 2017; 19(1): 1.

36. Zhu T, Gan J, Huang J, Li Y, Qu Y, Mu D. Association Between Perinatal Hypoxic-Ischemic Conditions and Attention-Deficit/Hyperactivity Disorder. Journal of Child Neurology 2016; 31: $1235-1244$.

37. Chen Q, Hartman CA, Haavik J, Harro J, Klungsøyr K, Hegvik T-A et al. Common psychiatric and metabolic comorbidity of adult attention-deficit/hyperactivity disorder: A population-based cross-sectional study. PloS one 2018; 13: e0204516.

38. Akmatov MK, Ermakova T, Bätzing J. Psychiatric and Nonpsychiatric Comorbidities Among Children With ADHD: An Exploratory Analysis of Nationwide Claims Data in Germany. Journal of attention disorders 2019: 108705471986577.

39. Maher GM, O'Keeffe GW, Kearney PM, Kenny LC, Dinan TG, Mattsson M et al. Association of hypertensive disorders of pregnancy with risk of neurodevelopmental disorders in offspring a systematic review and meta-analysis. JAMA Psychiatry, vol. 75. American Medical Association2018, pp 809-819.

40. Brand JS, Lawlor DA, Larsson H, Montgomery S. Association Between Hypertensive Disorders of Pregnancy and Neurodevelopmental Outcomes Among Offspring. JAMA Pediatr 2021. 
medRxiv preprint doi: https://doi.org/10.1101/2021.08.18.21262211; this version posted August 24, 2021. The copyright holder for this preprint (which was not certified by peer review) is the author/funder, who has granted medRxiv a license to display the preprint in perpetuity. It is made available under a CC-BY-NC-ND 4.0 International license .

41. Köhler-Forsberg O, Petersen L, Gasse C, Mortensen PB, Dalsgaard S, Yolken RH et al. A Nationwide Study in Denmark of the Association Between Treated Infections and the Subsequent Risk of Treated Mental Disorders in Children and Adolescents. JAMA Psychiatry 2018.

42. Lavebratt C, Yang LL, Giacobini MB, Forsell Y, Schalling M, Partonen T et al. Early exposure to antibiotic drugs and risk for psychiatric disorders: a population-based study. Translational Psychiatry 2019; 9: 1-12.

43. Lydholm CN, Köhler-Forsberg O, Nordentoft M, Yolken RH, Mortensen PB, Petersen L et al. Parental Infections Before, During, and After Pregnancy as Risk Factors for Mental Disorders in Childhood and Adolescence: A Nationwide Danish Study. Biological Psychiatry 2019; 85: 317-325.

44. Tylee DS, Sun J, Hess JL, Tahir MA, Sharma E, Malik R et al. Genetic correlations among psychiatric and immune-related phenotypes based on genome-wide association data. American Journal of Medical Genetics, Part B: Neuropsychiatric Genetics 2018; 177: 641-657.

45. Nielsen PR, Benros ME, Dalsgaard S. Associations Between Autoimmune Diseases and AttentionDeficit/Hyperactivity Disorder: A Nationwide Study. Journal of the American Academy of Child and Adolescent Psychiatry 2017; 56(3): 234-240.e231.

46. Nielsen TC, Nassar N, Shand AW, Jones H, Guastella AJ, Dale RC et al. Association of Maternal Autoimmune Disease With Attention-Deficit/Hyperactivity Disorder in Children. JAMA Pediatrics 2021: e205487-e205487.

47. Cortese S, Sun S, Zhang J, Sharma E, Chang Z, Kuja-Halkola R et al. Association between attention deficit hyperactivity disorder and asthma: a systematic review and meta-analysis and a Swedish population-based study. The lancet Psychiatry 2018; 0.

48. Miyazaki C, Koyama M, Ota E, Swa T, Mlunde LB, Amiya RM et al. Allergic diseases in children with attention deficit hyperactivity disorder: a systematic review and meta-analysis. $B M C$ psychiatry 2017; 17(1): 120.

49. Han VX, Patel S, Jones HF, Nielsen TC, Mohammad SS, Hofer MJ et al. Maternal acute and chronic inflammation in pregnancy is associated with common neurodevelopmental disorders: a systematic review. Translational Psychiatry 2021; 11(1): 71.

50. Liu X, Dalsgaard S, Munk-Olsen T, Li J, Wright RJ, Momen NC. Parental asthma occurrence, exacerbations and risk of attention-deficit/hyperactivity disorder. Brain, Behavior, and Immunity 2019; 82: 302-308.

51. Zhu Z, Zhu X, Liu CL, Shi H, Shen S, Yang Y et al. Shared genetics of asthma and mental health disorders: A large-scale genome-wide cross-trait analysis. European Respiratory Journal 2019; 54.

52. Schans JV, Çiçek R, de Vries TW, Hak E, Hoekstra PJ. Association of atopic diseases and attentiondeficit/hyperactivity disorder: A systematic review and meta-analyses. Neurosci Biobehav Rev 2017; 74(Pt A): 139-148. 
medRxiv preprint doi: https://doi.org/10.1101/2021.08.18.21262211; this version posted August 24, 2021. The copyright holder for this preprint (which was not certified by peer review) is the author/funder, who has granted medRxiv a license to display the preprint in perpetuity. It is made available under a CC-BY-NC-ND 4.0 International license .

53. van der Schans J, Pleiter JC, de Vries TW, Schuiling-Veninga CCM, Bos JHJ, Hoekstra PJ et al. Association between medication prescription for atopic diseases and attentiondeficit/hyperactivity disorder. Annals of Allergy, Asthma \& Immunology 2016; 117(2): 186-191.

54. Chang TH, Tai YH, Dai YX, Chang YT, Chen TJ, Chen MH. Risk of Atopic Diseases among Siblings of Patients with Attention-Deficit Hyperactivity Disorder: A Nationwide Population-Based Cohort Study. International archives of allergy and immunology 2019; 180(1): 37-43.

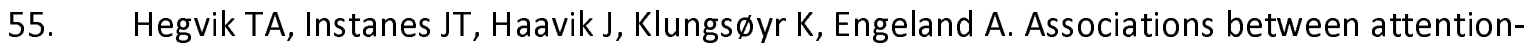
deficit/hyperactivity disorder and autoimmune diseases are modified by sex: a population-based cross-sectional study. European Child and Adolescent Psychiatry 2018; 27: 663-675.

56. Zeng Y, Tang Y, Yue Y, Li W, Qiu X, Hu P et al. Cumulative evidence for association of parental diabetes mellitus and attention-deficit/hyperactivity disorder. Neurosci Biobehav Rev 2020; 117: 129-139.

57. Brikell I, Ghirardi L, D'Onofrio BM, Dunn DW, Almqvist C, Dalsgaard S et al. Familial Liability to Epilepsy and Attention-Deficit/Hyperactivity Disorder: A Nationwide Cohort Study. Biological Psychiatry 2018; 83: 173-180.

58. Bertelsen EN, Larsen JT, Petersen L, Christensen J, Dalsgaard S. Childhood Epilepsy, Febrile Seizures, and Subsequent Risk of ADHD. Pediatrics 2016; 138(2).

59. Halmoy A, Klungsoyr K, Skjaerven R, Haavik J. Pre- and perinatal risk factors in adults with attention-deficit/hyperactivity disorder. Biol Psychiatry 2012; 71(5): 474-481.

60. Anttila V, Bulik-Sullivan B, Finucane HK, Walters RK, Bras J, Duncan L et al. Analysis of shared heritability in common disorders of the brain. Science 2018; 360: eaap8757.

61. Adeyemo BO, Biederman J, Zafonte R, Kagan E, Spencer TJ, Uchida M et al. Mild traumatic brain injury and ADHD: a systematic review of the literature and meta-analysis. Journal of attention disorders 2014; 18(7): 576-584.

62. Liou YJ, Wei HT, Chen MH, Hsu JW, Huang KL, Bai YM et al. Risk of Traumatic Brain Injury Among Children, Adolescents, and Young Adults With Attention-Deficit Hyperactivity Disorder in Taiwan. The Journal of adolescent health : official publication of the Society for Adolescent Medicine 2018; 63(2): 233-238.

63. Li D-J, Chen Y-L, Chen Y-Y, Hsiao RC, Lu W-H, Yen C-F. Increased Risk of Traumatic Injuries among Parents of Children with Attention Deficit/Hyperactivity Disorder: A Nationwide PopulationBased Study. International Journal of Environmental Research and Public Health 2021; 18(7): 3586.

64. Wei HT, Pan TL, Hsu JW, Huang KL, Bai YM, Ko NY et al. Risks of bipolar disorder, depressive disorder, and traumatic brain injury among siblings of patients with attention-deficit hyperactivity disorder. J Affect Disord 2019; 245: 335-339. 
medRxiv preprint doi: https://doi.org/10.1101/2021.08.18.21262211; this version posted August 24, 2021. The copyright holder for this preprint (which was not certified by peer review) is the author/funder, who has granted medRxiv a license to display the preprint in perpetuity. It is made available under a CC-BY-NC-ND 4.0 International license .

65. Jangmo A, Kuja-Halkola R, Pérez-Vigil A, Almqvist C, Bulik CM, D'Onofrio B et al. Attentiondeficit/hyperactivity disorder and occupational outcomes: The role of educational attainment, comorbid developmental disorders, and intellectual disability. PLOS ONE 2021; 16(3): e0247724.

66. Russell AE, Ford T, Williams R, Russell G. The Association Between Socioeconomic Disadvantage and Attention Deficit/Hyperactivity Disorder (ADHD): A Systematic Review. Child Psychiatry and Human Development, vol. 47. Springer New York LLC2016, pp 440-458.

67. Keilow M, Wu C, Obel C. Cumulative social disadvantage and risk of attention deficit hyperactivity disorder: Results from a nationwide cohort study. SSM - Population Health 2020; 10.

68. Rietveld CA, Patel PC. ADHD and later-life labor market outcomes in the United States. The European Journal of Health Economics 2019; 20(7): 949-967.

69. Erskine HE, Norman RE, Ferrari AJ, Chan GCK, Copeland WE, Whiteford HA et al. Long-Term Outcomes of Attention-Deficit/Hyperactivity Disorder and Conduct Disorder: A Systematic Review and Meta-Analysis. Journal of the American Academy of Child and Adolescent Psychiatry, vol. 55. Elsevier Inc.2016, pp 841-850.

70. Fleming M, Fitton CA, Steiner MFC, McLay JS, Clark D, King A et al. Educational and Health Outcomes of Children Treated for Attention-Deficit/Hyperactivity Disorder. JAMA Pediatr 2017; 171(7): e170691.

71. Selzam S, Ritchie SJ, Pingault JB, Reynolds CA, O'Reilly PF, Plomin R. Comparing Within- and Between-Family Polygenic Score Prediction. American journal of human genetics 2019; 105: 351363.

72. Zwicker A, Mackenzie LE, Drobinin V, Bagher AM, Howes Vallis E, Propper L et al.

Neurodevelopmental and genetic determinants of exposure to adversity among youth at risk for mental illness. Journal of Child Psychology and Psychiatry 2020; 61(5): 536-544.

73. Hua M-H, Huang K-L, Hsu J-W, Bai Y-M, Su T-P, Tsai S-J et al. Early Pregnancy Risk Among Adolescents With ADHD: A Nationwide Longitudinal Study. Journal of attention disorders 2020: 1087054719900232.

74. Min X, Li C, Yan Y. Parental Age and the Risk of ADHD in Offspring: A Systematic Review and Meta-Analysis. International Journal of Environmental Research and Public Health 2021; 18(9): 4939.

75. Ni G, Amare AT, Zhou X, Mills N, Gratten J, Lee SH. The genetic relationship between female reproductive traits and six psychiatric disorders. Scientific Reports 2019; 9(1): 12041.

76. Cheung K, Theule J. Parental Psychopathology in Families of Children with ADHD: A Metaanalysis. Journal of Child and Family Studies 2016; 25(12): 3451-3461. 
medRxiv preprint doi: https://doi.org/10.1101/2021.08.18.21262211; this version posted August 24, 2021. The copyright holder for this preprint

(which was not certified by peer review) is the author/funder, who has granted medRxiv a license to display the preprint in perpetuity.

It is made available under a CC-BY-NC-ND 4.0 International license .

77. McCoy BM, Rickert ME, Class QA, Larsson H, Lichtenstein P, D'Onofrio BM. Mediators of the association between parental severe mental illness and offspring neurodevelopmental problems. Annals of Epidemiology 2014; 24: 629-634.e621.

78. Consortium C-DGotPG, Lee PH, Anttila V, Won H, Feng Y-CA, Rosenthal J et al. Genome wide meta-analysis identifies genomic relationships, novel loci, and pleiotropic mechanisms across eight psychiatric disorders. bioRxiv 2019: 528117.

79. Brikell I, Larsson H, Lu Y, Pettersson E, Chen Q, Kuja-Halkola R et al. The contribution of common genetic risk variants for ADHD to a general factor of childhood psychopathology. Molecular Psychiatry 2020; 25(8): 1809-1821.

80. Riglin L, Thapar AK, Leppert B, Martin J, Richards A, Anney R et al. Using Genetics to Examine a General Liability to Childhood Psychopathology. Behav Genet 2020; 50(4): 213-220.

81. Wimberley T, Agerbo E, Horsdal HT, Ottosen C, Brikell I, Als TD et al. Genetic liability to ADHD and substance use disorders in individuals with ADHD. Addiction 2020; 115: 1368-1377. 
Table 1. Summary of prior literature on the phenotypic, familial and genetic links between ADHD and the studied risk factors

\begin{tabular}{|c|c|c|c|c|c|}
\hline Domain & Risk-factor & Phenotypic associations & Familial associations & $\begin{array}{c}\text { Gene-environment } \\
\text { correlation }\end{array}$ & $\begin{array}{c}\text { Gene-environment } \\
\text { interaction }\end{array}$ \\
\hline \multirow[t]{3}{*}{$\begin{array}{l}\text { Birth- } \\
\text { related }\end{array}$} & $\begin{array}{l}\text { Low birth } \\
\text { weight /very } \\
\text { preterm }\end{array}$ & OR=3.04 $(2.19,4.21)^{* 34}$ & $\begin{array}{l}\text { Sibling analyses OR/HR range } 2.36-2.44 \text {; } \\
\text { Twin-comparison show significantly } \\
\text { higher ADHD symptoms in co-twin with } \\
\text { lower birth-weight } * * 5\end{array}$ & $\begin{array}{l}\text { Birth weight } r_{g}=-0.13 \\
(0.04), p<0.0008^{3}\end{array}$ & $\mathrm{n} / \mathrm{a}$ \\
\hline & $\begin{array}{l}\text { Small for } \\
\text { gestational age }\end{array}$ & OR/RR range $1.13-1.30 * * 35$ & $\begin{array}{l}\text { Sibling analysis } \mathrm{HR}=2.3(2.0,2.8) ; \\
0.24 \mathrm{SD}(0.14-0.34) \text { higher mean ADHD } \\
\text { symptoms score } * * 5\end{array}$ & $\mathrm{n} / \mathrm{a}$ & $\mathrm{n} / \mathrm{a}$ \\
\hline & $\begin{array}{l}\text { Apgar score }<7 \\
\text { at } 5 \text { minutes }\end{array}$ & $\mathrm{OR}=1.31(1.12,1.54)^{* 36}$ & $\mathrm{n} / \mathrm{a}$ & $\mathrm{n} / \mathrm{a}$ & $\mathrm{n} / \mathrm{a}$ \\
\hline \multirow[t]{2}{*}{ Somatic } & $\begin{array}{l}\text { Hypertension } \\
\text { (during } \\
\text { pregnancy } \\
{[\text { HDP]) }}\end{array}$ & $\begin{array}{l}\text { Hypertension in adults } \\
\text { prevalence rate }=1.90 \\
(1.83-1.97)^{37} \\
\text { Hypertension in children } \\
\text { OR }=3.26(3.00-3.55)^{38}\end{array}$ & $\begin{array}{l}\text { HDP OR=1.29 }(1.22,1.36) * 39 \\
\text { HDP HR=1.10 } \\
(1.05,1.16) ; \\
\text { Siblings differentially exposed to HPD } \\
\text { HR }=1.09(0.95-1.24)^{40}\end{array}$ & $\begin{array}{l}\text { NS association of ADHD- } \\
\text { PRS with hypertension in a } \\
\text { general population sample } \\
(\mathrm{N}=7088) * * 11\end{array}$ & $\mathrm{n} / \mathrm{a}$ \\
\hline & Infections & $\begin{array}{l}\text { HR=2.09 }(1.78,2.46) \\
\text { hospital treated infections } \\
41 \\
\text { HR=1.56 }(1.34,1.82) \text { drug- } \\
\text { treatment for infections }{ }^{41} \\
\text { HRQ }=1.26(1.20,1.33) \text { drug- } \\
\text { treatment infections in first } \\
2 \text { years of life }{ }^{42}\end{array}$ & $\begin{array}{l}\text { Maternal pre-pregnancy: } 1.14 \\
(1.10,1.19) \text { drug-treated infection, } 1.22 \\
(1.09,1.38) \text { hospital treated infection }{ }^{43} \\
\text { In pregnancy: maternal } 1.13(1.09,1.17) \\
\text { drug-treated infection, } 1.22(1.12,1.33) \\
\text { hospital treated infection }{ }^{43} \\
\text { Post-pregnancy: } 1.09(1.06,1.14) \\
\text { drug-treated infection, } \\
\text { 1.11 (1.01,1.22) hospital treated } \\
\text { infection }{ }^{43} \\
\text { NS association with paternal infections } \\
43\end{array}$ & $\begin{array}{l}\text { Childhood ear infections } r_{g} \\
=0.20(0.05), p<2.0 \times 10^{-4} 44\end{array}$ & $\mathrm{n} / \mathrm{a}$ \\
\hline
\end{tabular}




\begin{tabular}{|c|c|c|c|c|}
\hline & & $\begin{array}{l}\text { NS association of maternal infection in } \\
\text { sibling analyses } * * 5 \\
\text { NS association of drug-treatment for } \\
\text { infections in first } 2 \text { years of life in sibling } \\
\text { analysis } * * 5\end{array}$ & & \\
\hline $\begin{array}{l}\text { Any } \\
\text { autoimmune } \\
\text { diseases }\end{array}$ & $\begin{array}{l}\text { Any autoimmune disease } \\
\text { IRR=1.24 }(95 \% \mathrm{Cl} 1.10-1.40) \\
45\end{array}$ & $\begin{array}{l}\text { Any maternal autoimmune disease } \\
H R=1.20(1.03-1.38)^{*} 46\end{array}$ & $\begin{array}{l}\text { Serum level of CRP } r_{g}=0.23 \\
(0.06) p \text {-value }<2.0 \times 10^{-4} 44 \\
\text { Psoriasis } r_{g}=0.23(0.07), p \text { - } \\
\text { value }<1.0 \times 10^{-3} 44 \\
\text { Rheumatoid arthritis } r_{g} \\
=0.16(0.05), p \text {-value }< \\
9.0 \times 10^{-4} 44 \\
\text { Tuberculosis susceptibility } \\
r_{g}=0.36(0.11), p \text {-value }<1 \\
.6 \times 10^{-3} 44 \\
N S \text { rG for remaining } \\
\text { autoimmune diseases after } \\
\text { multiple testing } \\
\text { correction }\end{array}$ & $\mathrm{n} / \mathrm{a}$ \\
\hline Asthma & $\begin{array}{l}\mathrm{OR}=1.53(1.41,1.65) * 47 \\
\mathrm{OR}=1.34(1.24-1.44) * 48\end{array}$ & $\begin{array}{l}\text { Maternal asthma OR/HR range } 1.41- \\
1.50^{* *} 49,50 \\
\text { Paternal asthma HR=1.13 (1.08-1.18) }\end{array}$ & $\begin{array}{l}\text { Asthma } r_{g}=0.20(0.05), p< \\
1.21 \times 10^{-0551}\end{array}$ & $n / a$ \\
\hline Atopic diseases & $\begin{array}{l}\text { Atopic dermatitis OR=1.32 } \\
(1.20,1.45) * 52 ; O R=1.43 \\
(1.09,1.88) * 48 \\
\text { Allergic rhinitis OR=1.52 } \\
(1.43,1.63) * 52 ; O R=1.59 \\
(1.13,2.23) * 48\end{array}$ & $\begin{array}{l}\text { Parental allergic rhinitis } \mathrm{OR}=1.3(1.1- \\
1.5)^{53} \\
\text { Sibling any atopic diseases } \mathrm{RR}=1.13 \\
(1.10-1.15)^{54} \\
\text { Sibling atopic dermatitis } \mathrm{RR}=1.10(1.04- \\
1.16)^{54}\end{array}$ & $\begin{array}{l}\text { Allergies } r_{g}=0.11(S E=0.04), \\
p=0.058\end{array}$ & $\mathrm{n} / \mathrm{a}$ \\
\hline
\end{tabular}




\begin{tabular}{|c|c|c|c|c|}
\hline & & $\begin{array}{l}\text { Sibling allergic rhinitis RR=1.17 (1.14- } \\
1.21)^{54}\end{array}$ & & \\
\hline $\begin{array}{l}\text { Type } 1 \text { diabetes } \\
\text { (T1D) }\end{array}$ & $\begin{array}{l}\text { T1D OR=1.30 }(1.20,1.40)^{38} \\
\text { T1D IRR=1.31 }(1.03,1.63)^{45} \\
\text { T1D NS in males and } \\
\text { females }\end{array}$ & $\begin{array}{l}\text { Maternal T1D OR=1.53(1.27,1.85)*46 } \\
\text { Paternal T1D OR= } 1.20(1.13,1.28)^{* 56}\end{array}$ & $\begin{array}{l}T 1 D r_{g}=-0.14(0.06) \\
p=0.1396^{44}\end{array}$ & $n / a$ \\
\hline Epilepsy & $\begin{array}{l}\mathrm{OR}=3.46(3.34,3.58)^{38} \\
\mathrm{OR}=3.47(3.33,3.62)^{57} \\
\mathrm{IRR}=2.72(2.53,2.91)^{58}\end{array}$ & $\begin{array}{l}\text { Maternal RR=1.7 }(1.1-2.7)^{59} \\
\text { Maternal OR=1.85 }(1.75-1.96)^{57} \\
\text { Paternal OR=1.64 (1.54-1.74) } \\
\text { Full-siblings OR=1.56 }(1.46-1.67) \\
\text { Maternal half-siblings OR=1.28 }(1.14- \\
1.43)^{57} \\
\text { Paternal half-siblings OR=1.10 (0.96- } \\
1.25)^{57} \\
\text { Cousins OR=1.15 (1.10-1.20) } \\
\mathrm{r}_{\mathrm{g}} \text { estimated using quantitative genetic } \\
\text { methods in sibling data }=0.21(0.02- \\
0.40)^{57}\end{array}$ & $\begin{array}{l}\text { Epilepsy } r_{g}=0.1408 \\
(S E=0.121), p=0.24\end{array}$ & $\mathrm{n} / \mathrm{a}$ \\
\hline $\begin{array}{l}\text { Traumatic brain } \\
\text { injury (TBI) }\end{array}$ & $\begin{array}{l}\text { Mild TBI RR=2.0 ( } z= \\
6.5) p<.0005 * 61 \\
\text { Any TBI HR=4.57 (4.31- } \\
\text {,4.85) }\end{array}$ & $\begin{array}{l}\text { Maternal TBI HR=1.45 (1.42-1.48) } \\
\text { Paternal TBI HR=1.21 }(1.17-1.24)^{63} \\
\text { Sibling TBI OR=1.24 (1.14-1.36) }\end{array}$ & $\mathrm{n} / \mathrm{a}$ & $\begin{array}{l}\text { A significant } \\
\text { interaction } \\
\text { between ADHD PRS } \\
\text { and TBI (mild TBI } \\
\text { vs. no TBI) (t1427 = } \\
-2.1, \mathrm{p}=0.04) \text {. } \\
\text { ADHD-PRS } \\
\text { positively } \\
\text { associated with } \\
\text { ADHD symptom } \\
\text { score in youths }\end{array}$ \\
\hline
\end{tabular}




\begin{tabular}{|c|c|c|c|c|c|}
\hline & & & & & $\begin{array}{l}\text { without TBI: } \\
t_{1224}=3.5, \mathrm{p}=0.005 \text {, } \\
\text { but not in those } \\
\text { with mild TBI: } \\
\left.t_{196}=20.4, p=.70\right)^{31}\end{array}$ \\
\hline \multirow[t]{3}{*}{$\begin{array}{l}\text { Psycho- } \\
\text { social }\end{array}$} & Low income & $\begin{array}{l}\text { ADHD individuals had an } \\
\text { income ratio=0.83 }(0.82, \\
0.84) \text {, equivalent to on } \\
\text { average } 17 \% \text { lower income } \\
\text { compared to individuals } \\
\text { without ADHD }\end{array}$ & $\begin{array}{l}\text { Low parental income OR range } 1.33- \\
4.51 * * 66 \\
b=0.023(0.02,0.02), p<0.001^{67} \\
\text { Sibling analysis HR } 1.37(1.07,1.75) \text {; } \\
\text { significant association with family } \\
\text { income decline and externalizing } \\
\text { problems } * * 5\end{array}$ & $\begin{array}{l}\text { ADHD-PRS negatively } \\
\text { associated with income in } \\
\text { general population: Beta=- } \\
0.172(0.04), p<0.01^{68}\end{array}$ & $\begin{array}{l}\text { NS interaction } \\
\text { between parental } \\
\text { income level and } \\
\text { ADHD-PRS in } \\
\text { iPSYCH }^{13}\end{array}$ \\
\hline & Low education & $\begin{array}{l}\text { Failure to complete } \\
\text { high school OR=3.70 } \\
(1.96,6.99) * 69 \\
\text { No tertiary education } \\
\text { OR=6.47 }(4.58,9.14) * 69 \\
\text { Lower academic } \\
\text { attainment OR=3.35 } \\
(3.00,3.75)^{70}\end{array}$ & $\begin{array}{l}\text { Low maternal education } \mathrm{OR}=1.91(1.20 \text {, } \\
3.03) * 66 \\
\text { Low paternal education } \mathrm{OR}= \\
2.1(1.27,3.47) * 66 \\
\text { Parental education } \leq \\
\text { compulsory school } \\
\text { ? }=0.035[3.5 \%](0.03,0.03) p<0.001^{67}\end{array}$ & $\begin{array}{l}\text { Years of education } r_{g}=-0.53 \\
(0.02), p<1.44 \times 10^{-80} 3 \\
\text { ADHD-PRS associated with } \\
\text { lower educational } \\
\text { attainment (within- } \\
\text { individual) in } 7 \text { out of } 9 \\
\text { studies } * * 11\end{array}$ & $\begin{array}{l}\text { NS interaction } \\
\text { between parental } \\
\text { education level and } \\
\text { ADHD-PRS in } \\
\text { iPSYCH }^{13}\end{array}$ \\
\hline & Unemployment & $\begin{array}{l}\text { Unemployment OR=1.97 } \\
(1.01,3.85) * 69 \\
\text { Unemployment } \mathrm{OR}=1.39 \\
(1.25,1.53)^{70} \\
\text { ADHD individuals had on } \\
\text { average } 12.19 \\
(11.89,12.49) \text { more days of }\end{array}$ & $\begin{array}{l}\text { Parental unemployment } \geq 6-12 \text { months } \\
b=0.021(0.02,0.02), p<0.0011^{67}\end{array}$ & $\begin{array}{l}\text { ADHD-PRS negatively } \\
\text { associated with } \\
\text { employment in general } \\
\text { population: } b=-0.107 \\
(0.04), p<0.01{ }^{68} \\
\text { Child ADHD-PRS associated } \\
\text { with lower family SES } b=- \\
0.17(-0.21,-0.13) \text {, }\end{array}$ & $\begin{array}{l}\text { NS interaction } \\
\text { between parental } \\
\text { unemployment and } \\
\text { ADHD-PRS in } \\
\text { iPSYCH }^{13}\end{array}$ \\
\hline
\end{tabular}




\begin{tabular}{|c|c|c|c|c|}
\hline & $\begin{array}{l}\text { unemployment } \\
65\end{array}$ & & $\begin{array}{l}p<1.32 \times 10^{13} 71 \text { and higher } \\
\text { SES adversity } b=0.10(0.01 \\
0.20), p=0.028^{72}\end{array}$ & \\
\hline $\begin{array}{l}\text { Single } \\
\text { parenthood }\end{array}$ & $\mathrm{n} / \mathrm{a}$ & $\mathrm{OR}=1.28(1.08-1.52) * 66$ & $\mathrm{n} / \mathrm{a}$ & $\mathrm{n} / \mathrm{a}$ \\
\hline $\begin{array}{l}\text { Age at child } \\
\text { birth }\end{array}$ & $\begin{array}{l}\text { Early pregnancy OR=2.77 } \\
(0.67,11.37)^{* 69} \\
\text { Early pregnancy HR }=2.30 \\
(1.94,2.73)^{73}\end{array}$ & $\begin{array}{l}\text { Lowest maternal age category } \\
\text { OR=1.49 }(1.19,1.87) * 74 \\
\text { Lowest paternal age category OR= } \\
1.75(1.31,2.36) * 74 \\
\text { Non-linear association of paternal age } \\
(p<0.005) ; \text { ADHD risk highest in fathers } \\
\text { aged }<20,2^{\text {nd }} \text { highest in fathers aged } \geq \\
45, \text { compared to fathers aged } 31-15 \\
\text { years. * } 74 \\
\text { Younger maternal age NS or protective } \\
\text { in siblings analyses. Higher paternal age } \\
\text { associated with increased risk in } 1 \\
\text { sibling analysis. ** }\end{array}$ & $\begin{array}{l}\text { Age at first birth } r_{g}=-0.612 \\
(0.034), p=3.69 \times 10^{-613} \\
\text { Age at first birth } r_{g} \\
=-0.68 \text { ? }(0.034, p=1.86 \\
\times 10^{89} \text { and ADHD-PRS } \\
\text { associated with age at first } \\
\text { birth } R^{2}=1.10 \times 10^{-02}, p< \\
1.20 \times 10^{303} 75\end{array}$ & $\mathrm{n} / \mathrm{a}$ \\
\hline $\begin{array}{l}\text { Parental } \\
\text { psychiatric } \\
\text { disorder }\end{array}$ & $\begin{array}{l}\text { Comorbid psychiatric and } \\
\text { substance use disorders in } \\
\text { individuals with ADHD OR= } \\
2.53(1.48,4.32) * 69\end{array}$ & $\begin{array}{l}\text { Any parental psychopathology RR=2.85 } \\
(1.77,4.59) * 76 \\
\text { Maternal history of psychiatric } \\
\text { disorders HR=2.16 }(1.97,2.37))^{77} \\
\text { Paternal history of psychiatric disorders } \\
H R=2.21(2.01,2.43)^{77}\end{array}$ & $\begin{array}{l}\mathrm{r}_{\mathrm{g}} \text { range } 0.13-0.74 \text { with } \\
\text { externalizing disorders, } \\
\text { intellectual disability, } \\
\text { alcohol dependence, } \\
\text { depression, autism, } \\
\text { tourette's disorder, bipolar } \\
\text { disorder and schizophrenia, } \\
4,78 \\
\text { ADHD-PRS significantly } \\
\text { associated with a general } \\
\text { psychopathology factor in } \\
\text { children } 79,80\end{array}$ & $\begin{array}{l}\text { NS interaction } \\
\text { between parental } \\
\text { unemployment and } \\
\text { ADHD-PRS in } \\
\text { iPSYCH }^{13}\end{array}$ \\
\hline
\end{tabular}




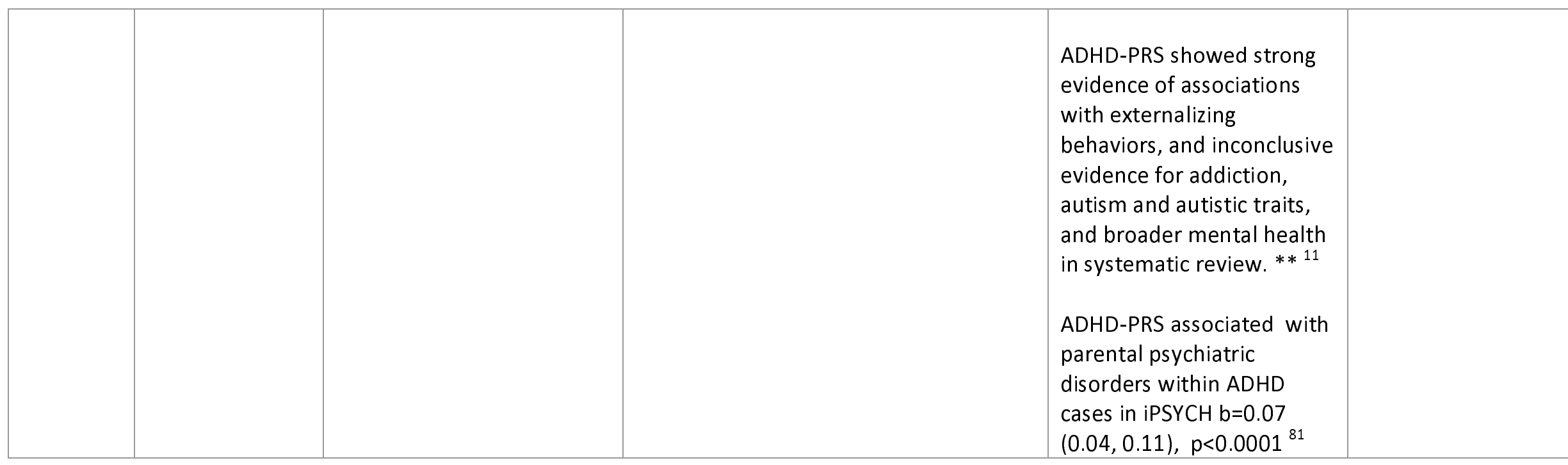

Note: For phenotypic and familial associations, we preferentially present pooled and, when available, adjusted, risk-estimates from the largest available published meta-analyses, followed by evidence from systematic reviews. Otherwise, we present estimates from large-scale population studies, prioritized based on sample size and the inclusion of clinically diagnosed cases. Associations are reported as risk estimates (RR, OR, HR) with 95\% confidence intervals ( $\mathrm{Cls}$ ) in brackets. For gene-environment correlation and interactions, we present results of the largest available genetic correlation analyses using the linkage disequilibrium score regression (LDSC) method, and summarize the available ADHD-PRS literature. Genetic correlations $\left(r_{\mathrm{g}}\right)$ are reported with standard errors (SE) in brackets and p-values corrected for multiple testing according to method stated in the cited publication. PRS associations are presented based on information provided in the cited study.

Abbreviations; RR, risk ratio. OR, odds ratio. HR, hazard ratio. $t$, $t$-test(n-1). NS, not significant. $n / a$, no available (i.e., no studies found). PRS, polygenic risk score. $r_{g}$, genetic correlation.

"Pooled, and when reported adjusted, risk estimates from cited meta-analysis.

${ }^{* *}$ Range of estimate from cited systematic review 
Table 2. Genetic confounding of ADHD risk-factors associations with ADHD case-control status, expressed as incidence rate ratios (IRRs) with 95\% confidence intervals (Cls)

\begin{tabular}{|c|c|c|c|c|c|c|c|c|c|c|c|c|c|c|}
\hline \multirow[b]{2}{*}{ Domain } & \multirow[b]{2}{*}{ Risk factor } & \multirow[b]{2}{*}{ Level } & \multicolumn{3}{|c|}{$\begin{array}{l}\text { Model } 1 \\
\text { (minimally } \\
\text { adjusted) }\end{array}$} & \multicolumn{3}{|c|}{$\begin{array}{l}\text { Model } 2 \\
\text { (ADHD-PRS } \\
\text { adjusted) }\end{array}$} & \multicolumn{3}{|c|}{$\begin{array}{c}\text { Model } 3 \\
\text { (parental psychiatric } \\
\text { history adjusted) }\end{array}$} & \multicolumn{3}{|c|}{$\begin{array}{c}\text { Model } 4 \\
\text { (Fully adjusted) }\end{array}$} \\
\hline & & & IRR & $\mathbf{L C l}$ & $\mathrm{UCl}$ & IRR & LCl & UCl & IRR & $\mathbf{L C l}$ & $\mathrm{UCl}$ & IRR & $\mathbf{L C l}$ & $\mathrm{UCl}$ \\
\hline \multirow[t]{9}{*}{ Birth-related } & \multirow[t]{2}{*}{ Sex } & Female & 0.37 & 0.35 & 0.39 & 0.37 & 0.35 & 0.39 & 0.37 & 0.35 & 0.39 & 0.37 & 0.35 & 0.39 \\
\hline & & Male & Ref & & & Ref & & & Ref & & & Ref & & \\
\hline & \multirow[t]{3}{*}{ Birth weight } & $<2500 \mathrm{~g}$ & 1.85 & 1.65 & 2.08 & 1.91 & 1.69 & 2.15 & 1.74 & 1.55 & 1.96 & 1.79 & 1.58 & 2.03 \\
\hline & & $2500-3999 \mathrm{~g}$ & Ref & & & Ref & & & Ref & & & Ref & & Ref \\
\hline & & $\geq 4000 \mathrm{~g}$ & 0.86 & 0.81 & 0.92 & 0.87 & 0.82 & 0.92 & 0.88 & 0.83 & 0.93 & 0.88 & 0.82 & 0.94 \\
\hline & \multirow[t]{2}{*}{ Small for gestational age } & No & Ref & & & Ref & & & Ref & & & Ref & & Ref \\
\hline & & Yes & 1.50 & 1.39 & 1.61 & 1.46 & 1.35 & 1.58 & 1.43 & 1.33 & 1.55 & 1.39 & 1.29 & 1.51 \\
\hline & \multirow[t]{2}{*}{ Apgar score at 5 minutes } & 10 & Ref & & & Ref & & & Ref & & & Ref & & \\
\hline & & $<10$ & 1.20 & 1.10 & 1.30 & 1.20 & 1.09 & 1.31 & 1.19 & 1.09 & 1.30 & 1.19 & 1.09 & 1.30 \\
\hline \multirow[t]{9}{*}{ Somatic } & \multirow{2}{*}{$\begin{array}{l}\text { Maternal hypertensive } \\
\text { disorders during } \\
\text { pregnancy }\end{array}$} & No & Ref & & & Ref & & & Ref & & & Ref & & \\
\hline & & Yes & 1.10 & 0.91 & 1.33 & 1.12 & 0.92 & 1.37 & 1.10 & 0.90 & 1.34 & 1.11 & 0.90 & 1.36 \\
\hline & \multirow{2}{*}{$\begin{array}{l}\text { Maternal infection } \\
\text { during pregnancy }\end{array}$} & No & Ref & & & Ref & & & Ref & & & Ref & & \\
\hline & & Yes & 1.64 & 1.45 & 1.85 & 1.59 & 1.40 & 1.81 & 1.56 & 1.38 & 1.77 & 1.53 & 1.34 & 1.74 \\
\hline & \multirow{2}{*}{$\begin{array}{l}\text { Maternal autoimmune } \\
\text { disorder by child's } 5^{\text {th }} \\
\text { birthday }\end{array}$} & No & Ref & & & Ref & & & Ref & & & Ref & & \\
\hline & & Yes & 1.08 & 0.94 & 1.24 & 1.03 & 0.89 & 1.19 & 1.02 & 0.89 & 1.18 & 0.98 & 0.85 & 1.14 \\
\hline & \multirow{2}{*}{$\begin{array}{l}\text { Paternal autoimmune } \\
\text { disorder by child's } 5^{\text {th }} \\
\text { birthday }\end{array}$} & No & Ref & & & Ref & & & Ref & & & Ref & & \\
\hline & & Yes & 1.21 & 1.03 & 1.43 & 1.23 & 1.04 & 1.47 & 1.18 & 0.99 & 1.40 & 1.18 & 0.99 & 1.42 \\
\hline & 1 infection & No & Ref & & & Ref & & & Ref & & & Ref & & \\
\hline
\end{tabular}




\begin{tabular}{|c|c|c|c|c|c|c|c|c|c|c|c|c|c|c|}
\hline & & Yes & 1.56 & 1.49 & 1.63 & 1.52 & 1.45 & 1.60 & 1.52 & 1.45 & 1.59 & 1.49 & 1.42 & 1.57 \\
\hline & \multirow[t]{2}{*}{$\geq 5$ infections } & No & Ref & & & Ref & & & Ref & \multicolumn{5}{|c|}{ Ref } \\
\hline & & Yes & 2.20 & 1.93 & 2.52 & 2.15 & 1.87 & 2.47 & 2.00 & 1.74 & 2.30 & 1.94 & 1.68 & 2.25 \\
\hline & \multirow[t]{2}{*}{ Asthma } & No & Ref & & & Ref & & & Ref & \multicolumn{5}{|c|}{ Ref } \\
\hline & & Yes & 1.46 & 1.37 & 1.55 & 1.42 & 1.33 & 1.52 & 1.42 & 1.33 & 1.52 & 1.39 & 1.30 & 1.49 \\
\hline & \multirow[t]{2}{*}{ Atopic disease } & No & Ref & & & Ref & & & Ref & \multicolumn{5}{|c|}{ Ref } \\
\hline & & Yes & 0.97 & 0.89 & 1.06 & 0.97 & 0.88 & 1.06 & 0.98 & 0.89 & 1.07 & 0.98 & 0.89 & 1.08 \\
\hline & \multirow[t]{2}{*}{ Type 1 diabetes } & No & Ref & & & Ref & & & Ref & \multicolumn{5}{|c|}{ Ref } \\
\hline & & Yes & 0.87 & 0.58 & 1.30 & 0.95 & 0.63 & 1.44 & 0.89 & 0.59 & 1.33 & 0.97 & 0.64 & 1.48 \\
\hline & \multirow[t]{2}{*}{ Epilepsy } & No & Ref & & & Ref & & & Ref & \multicolumn{5}{|c|}{ Ref } \\
\hline & & Yes & 2.38 & 2.06 & 2.75 & 2.37 & 2.03 & 2.77 & 2.29 & 1.97 & 2.66 & 2.30 & 1.97 & 2.70 \\
\hline & \multirow[t]{3}{*}{ Traumatic brain injury } & No & Ref & & & Ref & & & Ref & \multicolumn{5}{|c|}{ Ref } \\
\hline & & Mild & 1.94 & 1.78 & 2.11 & 1.85 & 1.69 & 2.03 & 1.88 & 1.72 & 2.06 & 1.79 & 1.63 & 1.97 \\
\hline & & Severe & 1.94 & 1.63 & 2.32 & 1.88 & 1.56 & 2.25 & 1.84 & 1.53 & 2.21 & 1.78 & 1.47 & 2.15 \\
\hline \multirow[t]{10}{*}{ Psychosocial } & \multirow[t]{5}{*}{ Maternal income at birth } & 1 quintile & 2.59 & 2.40 & 2.80 & 2.41 & 2.22 & 2.60 & 2.42 & 2.24 & 2.62 & 2.25 & 2.08 & 2.44 \\
\hline & & 2 quintile & 2.19 & 2.02 & 2.37 & 2.04 & 1.88 & 2.21 & 2.11 & 1.95 & 2.29 & 1.98 & 1.82 & 2.15 \\
\hline & & 3 quintile & 1.81 & 1.67 & 1.95 & 1.75 & 1.61 & 1.90 & 1.78 & 1.64 & 1.92 & 1.72 & 1.59 & 1.87 \\
\hline & & 4 quintile & 1.39 & 1.28 & 1.51 & 1.36 & 1.25 & 1.48 & 1.38 & 1.27 & 1.49 & 1.35 & 1.24 & 1.47 \\
\hline & & 5 quintile & Ref & & & Ref & & & Ref & \multicolumn{5}{|c|}{ Ref } \\
\hline & \multirow[t]{5}{*}{ Paternal income at birth } & 1 quintile & 2.90 & 2.69 & 3.13 & 2.73 & 2.52 & 2.95 & 2.65 & 2.45 & 2.87 & 2.50 & 2.30 & 2.71 \\
\hline & & 2 quintile & 2.13 & 1.97 & 2.31 & 2.02 & 1.86 & 2.19 & 2.07 & 1.91 & 2.24 & 1.97 & 1.81 & 2.14 \\
\hline & & 3 quintile & 1.70 & 1.57 & 1.84 & 1.66 & 1.53 & 1.80 & 1.69 & 1.56 & 1.83 & 1.65 & 1.51 & 1.79 \\
\hline & & 4 quintile & 1.48 & 1.36 & 1.61 & 1.47 & 1.35 & 1.60 & 1.46 & 1.35 & 1.59 & 1.45 & 1.34 & 1.58 \\
\hline & & 5 quintile & Ref & & & Ref & & & Ref & & & Ref & & \\
\hline
\end{tabular}




\begin{tabular}{|c|c|c|c|c|c|c|c|c|c|c|c|c|c|}
\hline \multirow{3}{*}{$\begin{array}{l}\text { Maternal education at } \\
\text { birth }\end{array}$} & Elementary & 3.47 & 3.24 & 3.72 & 3.15 & 2.94 & 3.38 & 3.24 & 3.02 & 3.47 & 2.96 & 2.75 & 3.17 \\
\hline & High school & 1.71 & 1.60 & 1.82 & 1.65 & 1.55 & 1.76 & 1.69 & 1.59 & 1.81 & 1.64 & 1.53 & 1.75 \\
\hline & $\begin{array}{l}\text { Academic } \\
\text { degree }\end{array}$ & Ref & & & Ref & & & Ref & & & Ref & & \\
\hline \multirow{3}{*}{$\begin{array}{l}\text { Paternal education at } \\
\text { birth }\end{array}$} & Elementary & 3.68 & 3.42 & 3.96 & 3.34 & 3.09 & 3.60 & 3.47 & 3.22 & 3.74 & 3.15 & 2.92 & 3.40 \\
\hline & High school & 1.91 & 1.78 & 2.04 & 1.82 & 1.70 & 1.95 & 1.87 & 1.75 & 2.01 & 1.79 & 1.67 & 1.92 \\
\hline & $\begin{array}{l}\text { Academic } \\
\text { degree }\end{array}$ & Ref & & & Ref & & & Ref & & & Ref & & \\
\hline \multirow{2}{*}{$\begin{array}{l}\text { Maternal employment at } \\
\text { birth }\end{array}$} & $\ln$ & Ref & & & Ref & & & Ref & & & Ref & & \\
\hline & Out of & 2.42 & 1.82 & 3.23 & 2.30 & 1.70 & 3.10 & 1.59 & 1.16 & 2.18 & 1.55 & 1.12 & 2.14 \\
\hline \multirow{2}{*}{$\begin{array}{l}\text { Paternal employment at } \\
\text { birth }\end{array}$} & In & Ref & & & Ref & & & Ref & & & Ref & & \\
\hline & Out of & 2.75 & 2.08 & 3.64 & 2.85 & 2.14 & 3.79 & 2.07 & 1.53 & 2.79 & 2.19 & 1.62 & 2.95 \\
\hline \multirow{6}{*}{$\begin{array}{l}\text { Living in a single parent } \\
\text { household in first five } \\
\text { years of life }\end{array}$} & No & Ref & & & Ref & & & Ref & & & Ref & & \\
\hline & 1 year & 2.12 & 1.94 & 2.31 & 2.04 & 1.86 & 2.23 & 2.00 & 1.82 & 2.19 & 1.93 & 1.76 & 2.12 \\
\hline & 2 years & 2.76 & 2.50 & 3.05 & 2.54 & 2.29 & 2.82 & 2.56 & 2.31 & 2.84 & 2.35 & 2.11 & 2.62 \\
\hline & 3 years & 2.69 & 2.43 & 2.99 & 2.45 & 2.20 & 2.74 & 2.45 & 2.20 & 2.73 & 2.25 & 2.01 & 2.51 \\
\hline & 4 years & 3.01 & 2.68 & 3.37 & 2.76 & 2.45 & 3.12 & 2.75 & 2.45 & 3.09 & 2.55 & 2.26 & 2.88 \\
\hline & 5 years & 3.01 & 2.69 & 3.37 & 2.73 & 2.43 & 3.08 & 2.71 & 2.41 & 3.04 & 2.47 & 2.19 & 2.79 \\
\hline \multirow[t]{5}{*}{ Maternal age at birth } & $<20$ & 2.65 & 2.30 & 3.05 & 2.40 & 2.07 & 2.79 & 2.44 & 2.10 & 2.82 & 2.23 & 1.92 & 2.60 \\
\hline & $20-24$ & 1.69 & 1.59 & 1.80 & 1.59 & 1.49 & 1.70 & 1.64 & 1.54 & 1.74 & 1.54 & 1.44 & 1.65 \\
\hline & $25-29$ & Ref & & & Ref & & & Ref & & & Ref & & \\
\hline & $30-34$ & 0.77 & 0.73 & 0.82 & 0.78 & 0.73 & 0.82 & 0.77 & 0.73 & 0.82 & 0.78 & 0.74 & 0.83 \\
\hline & $\geq 35$ & 0.75 & 0.69 & 0.81 & 0.76 & 0.70 & 0.83 & 0.73 & 0.67 & 0.79 & 0.74 & 0.68 & 0.81 \\
\hline \multirow[t]{2}{*}{ Paternal age at birth } & $<20$ & 2.26 & 1.73 & 2.95 & 2.19 & 1.66 & 2.90 & 2.13 & 1.62 & 2.79 & 2.07 & 1.54 & 2.78 \\
\hline & $20-24$ & 1.78 & 1.65 & 1.93 & 1.66 & 1.53 & 1.80 & 1.72 & 1.58 & 1.86 & 1.61 & 1.48 & 1.75 \\
\hline
\end{tabular}




\begin{tabular}{lcccccccccccc}
\hline $25-29$ & Ref & \multicolumn{3}{c}{ Ref } & \multicolumn{3}{c}{ Ref } & \multicolumn{5}{c}{ Ref } \\
\hline $30-34$ & 0.78 & 0.73 & 0.82 & 0.79 & 0.74 & 0.84 & 0.78 & 0.73 & 0.83 & 0.79 & 0.74 & 0.84 \\
\hline $35-39$ & 0.76 & 0.71 & 0.82 & 0.77 & 0.72 & 0.83 & 0.76 & 0.71 & 0.82 & 0.77 & 0.72 & 0.83 \\
\hline$\geq 40$ & 0.83 & 0.75 & 0.91 & 0.85 & 0.77 & 0.94 & 0.79 & 0.72 & 0.88 & 0.82 & 0.74 & 0.91 \\
\hline
\end{tabular}

Note: Incidence rate ratios (IRRs) with 95\% Cls, adjusted for sex, birth-year and first four PCs (Model 1). To evaluate if associations were confounded by polygenic liability for ADHD, we further adjusted the models for ADHD-PRS (Model 2), parental psychiatric history (Model 3), and both (Model 4). Significant association are highlighted in bold.

Abbreviations: IRR, incidence rate ratio. LCl, lower 95\% confidence interval. UCI, upper 95\% confidence interval. NA, not applicable. Ref, reference category 
medRxiv preprint doi: https://doi.org/10.1101/2021.08.18.21262211; this version posted August 24, 2021. The copyright holder for this preprint (which was not certified by peer review) is the author/funder, who has granted medRxiv a license to display the preprint in perpetuity.

It is made available under a CC-BY-NC-ND 4.0 International license .

Figure 1. Gene-environment associations of ADHD polygenic risk score with ADHD risk-factors in the

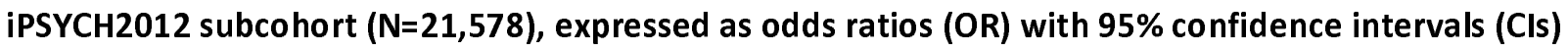

Domain $\boldsymbol{\phi}$ Pregnancy-related $\uparrow$ Psychosocial $\boldsymbol{\phi}$ Somatic

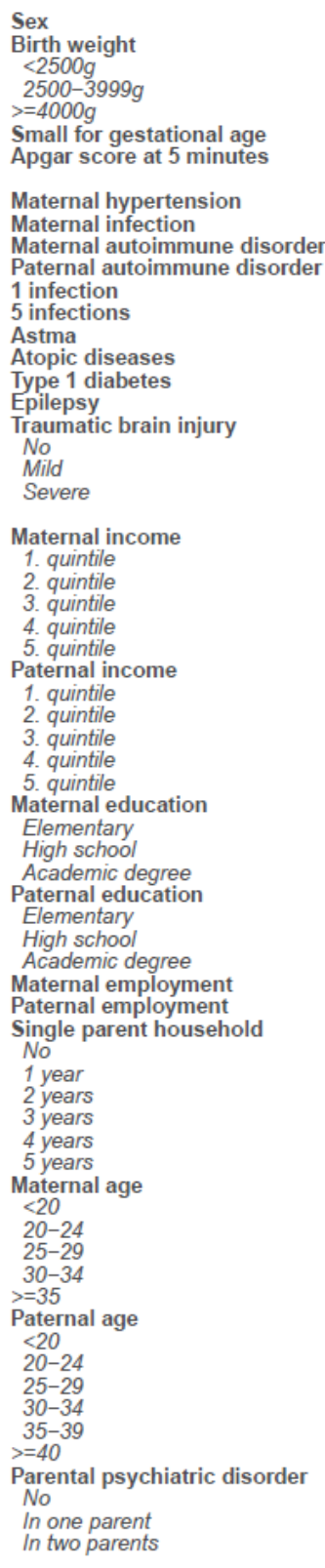

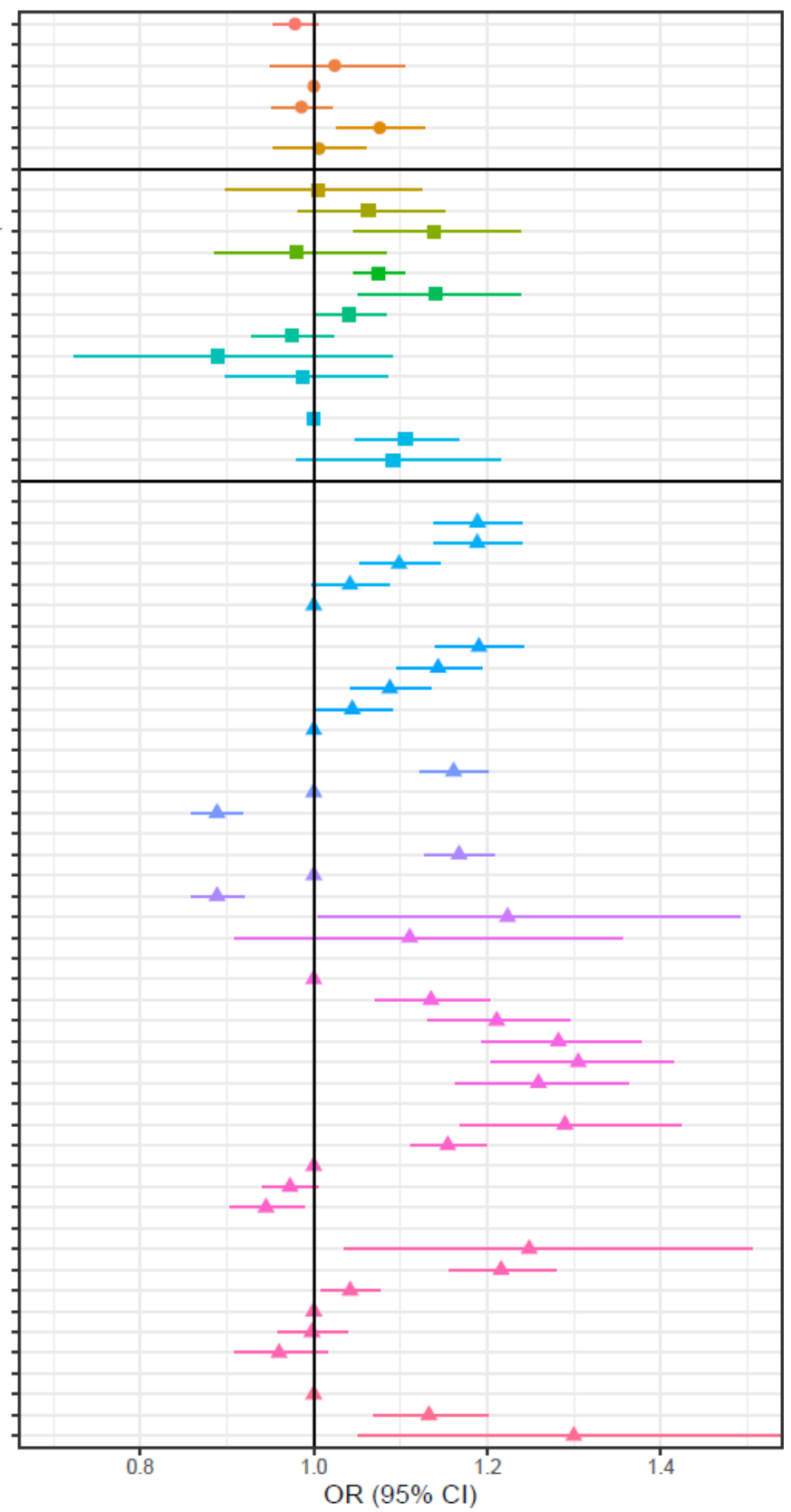

Note: Odds ratios and $95 \% \mathrm{Cl}$ reflect the increase in risk of exposure by one per standard deviation increase in the ADHD-PRS. Significant associations are highlighted in bold. ORs for binary exposures (0/1) are shown without reference. ORs for exposures with $\geq$ three levels are shown with reference. For exposure definitions, see Table S1. Abbreviations: OR, odds ratio. LCl, lower $95 \%$ confidence interval. $\mathrm{UCl}$, upper $95 \%$ confidence interval. PRS, polygenic risk score 
Figure 2. Gene-environment interactions showing the differential linear effect of ADHD-PRS across levels of risk-factors on ADHD case-control status, expressed as incidence rate ratios (IRRs) with $95 \%$ confidence intervals (Cls)
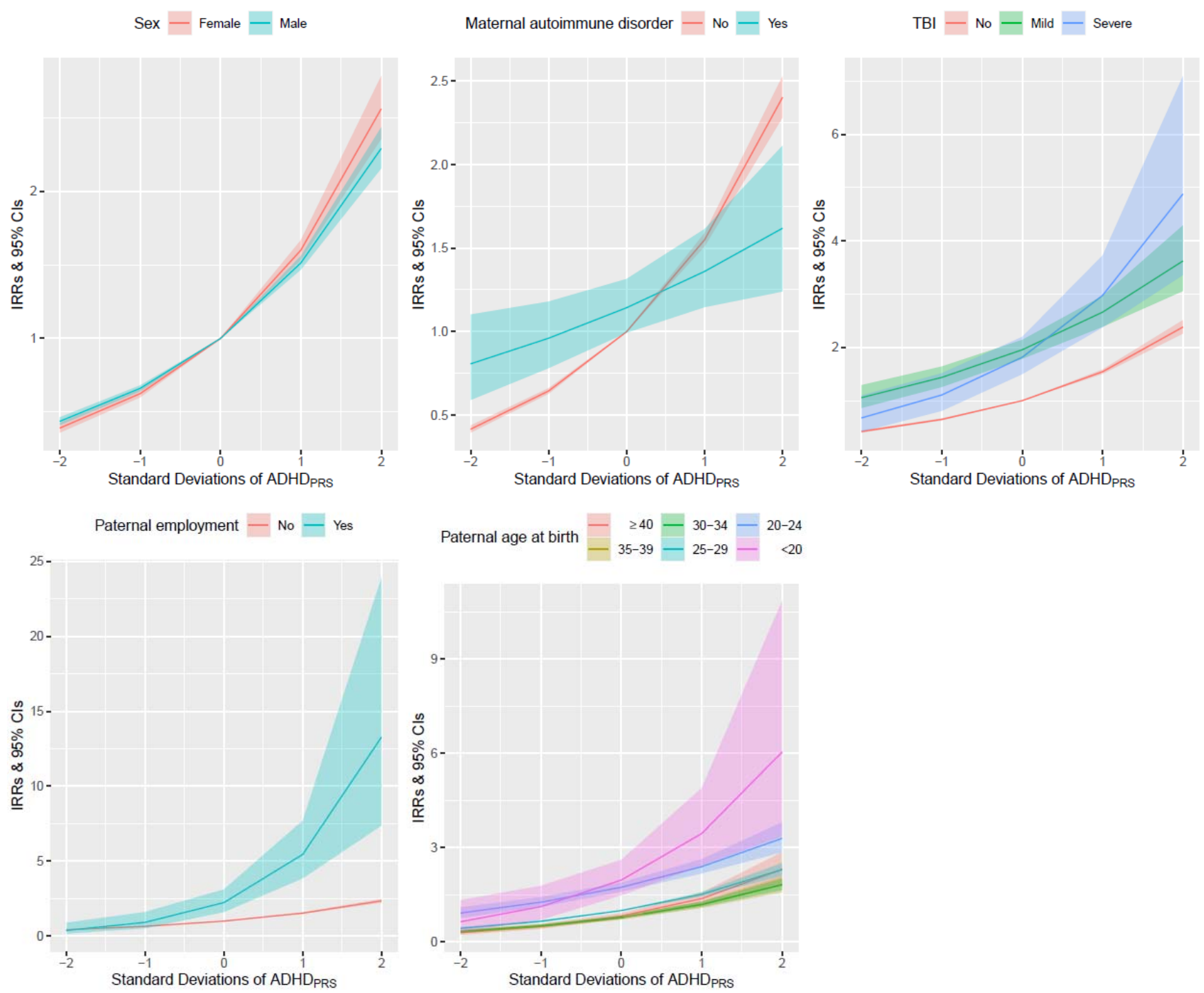

Note: Incidence rate ratios (IRRs) and 95\% confidence intervals ( $\mathrm{Cls}$ ) reflects the differential linear effect of a one standard deviation increase in ADHD-PRS across levels of each risk-factor, adjusted for sex, birth-year, and the first four PCs. Results are shown only for risk-factor showing tentative evidence of interaction with ADHD-PRS $(p<0.05)$ in interaction analyses. Full results are presented in Table S3. For exposure definitions, see Table S1. Abbreviations: TBI, traumatic brain injury. PRS, polygenic risk score 